\title{
A BUILDING ENERGY PERFORMANCE EVALUATION PROGRAM (EnAd) FOR ARCHITECTURAL DESIGN PROCESS ${ }^{1}$
}

\section{MIMMARİ TASARIM SÜRECI İÇIN BINAA ENERJI PERFORMANSI DEĞERLENDIRME PROGRAMI (EnAd)}

\author{
Fatma Zehra ÇAKICI ${ }^{1}$ Arzu GÖNENÇ SORGUÇ
}

${ }^{1}$ Department of Architecture, Faculty of Architecture and Design, Ataturk University, Erzurum / Turkey

${ }^{2}$ Department of Architecture, Faculty of Architecture, Middle East Technical University, Ankara / Turkey

Öz: Binalarda enerji performansı çağdaş mimarlığın en kritik konulardan biri haline gelmiştir. Hesaplamalı araçlardaki teknolojik gelişmeler sayesinde, inşaat başlamadan önce binaların enerji performanslarının analizi mümkündür. Ancak, karmaşık katı modeller ve yazılım üzerine uzmanlaşma gerektiren enerji performans değerlendirme araçlarının çoğu tasarım sonrası süreçte kullanılabilmektedir. Tasarım kararlarının binaların enerji performansı üzerinde önemli etkileri olduğundan, bu tür değerlendirme araçlarının tasarım sürecinin başından itibaren kullanılması büyük önem taşımaktadır. Bu bağlamda, yasalar ve bina tasarım süreci göz önüne alınarak, binaların enerji performansını değerlendirmek amacıyla EnAd isimli bir bilgisayar programı geliştirilmiştir. İleri uzmanlık gerektirmeyen bu program, tasarım sürecinin herhangi bir aşamasında kullanılmak üzere tasarlanmıştır. TS EN ISO 13790 tarafindan belirlenen aylık hesaplama yöntemini kullanan program, Avrupa Birliğinin Binalarda Enerji Performansı Direktifi ve konuya ilişsin mevcut Türk mevzuatına dayanılarak geliştirilmiş̧tir. Geliştirilen tasarım-destek aracının kullanılabilirliği, geçerliliği, güvenirliği ve hassasiyeti kullanılabilirlik ve yakınsama testleri ile kanıtlanmıştır.

Anahtar Kelimeler: Enerji Performansı, Binalarda Enerji Performansı, EPBD, Performans Değerlendirme Programı, Aylık Hesaplama Yöntemi, TS EN ISO 1379
Abstract: Energy performance in buildings has become one of the most broadly debated subjects in contemporary architecture. Although technological advances in computational tools, make possible the analysis of a building energy performance before construction starts; most of these performance evaluation tools, developed by different countries based on different building codes and standards, requiring complex solid models and high technical knowledge in the field, can only be used during the post design phases. However, it is evident that any design decision in any phase of the design process directly affects the energy performance of a building. Therefore the use of such evaluation tools from the very beginning of the design process has an outmost importance. In this context, a building energy performance evaluation program, entitled as Energy Performance Advisor (EnAd), is developed for evaluating the energy performance of buildings considering not only the legal framework of Turkey, but also the building design process. The program does not require advanced expertise, and is intended to be usable in any phase of the design process. EnAd, using the monthly calculation method of TS EN ISO 13790 , is developed based on the European Union Directive on Energy Performance in Buildings (EPBD) and the current Turkish legislation on the subject. The validity, reliability, precision and usability of EnAd as a design-support tool has been proved through the usability and convergence tests conducted.

Key Words: Energy Performance, Energy Performance in Buildings, EPBD, Performance Evaluation Program, Monthly Calculation Method, TS EN ISO 1379

Doi: 10.17365/TMD.2017.1.011.x

(1) Sorumlu Yazar: Fatma Zehra ÇAKICI, Atatürk Üniversitesi Mimarlık ve Tasarım Fakültesi Mimarlı Bölümü Erzurum / Türkiye, fzehra.cakici@atauni.edu.tr Geliş Tarihi / Received: 07.09.2016 Düzeltme Tarihi / Revision Date: 18.01.2017-29.01.2017 Kabul Tarihi / Accepted: 20.02.2017 Makalenin Türü: Typeofarticle (Araşturma Uygulama /Research - Application) Çıkar Çatışması / Conflict of Interest:Yok / None“Etik Kurul Raporu Yok - None of Ethics Commit 


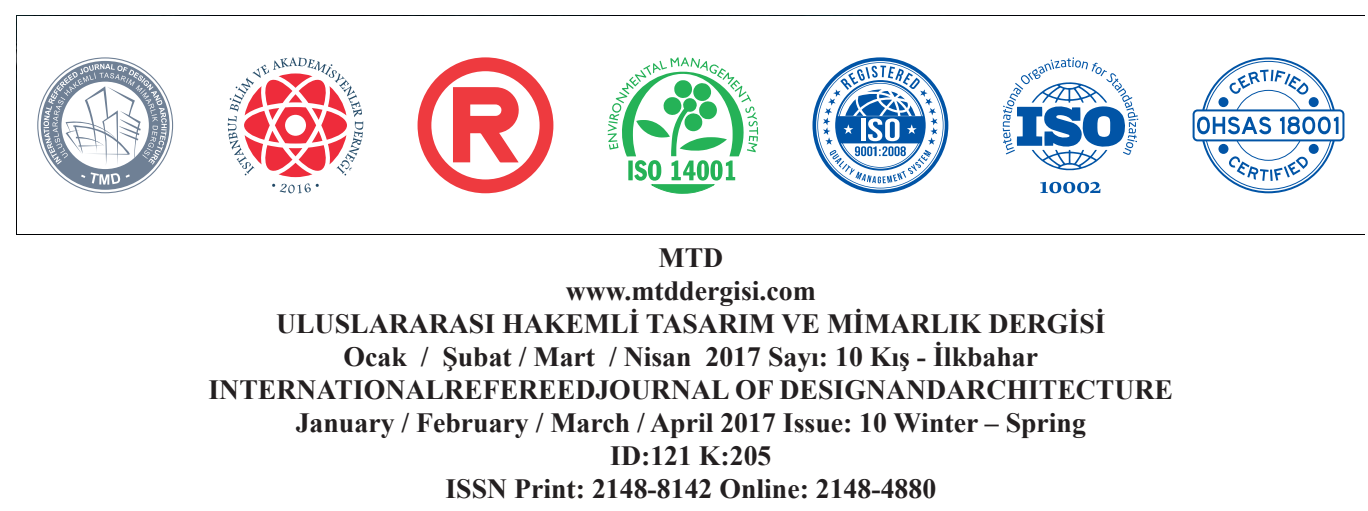

ISSN Print: 2148-8142 Online: 2148-4880
(ISO 18001-OH-0090-13001706 / ISO 14001-EM-0090-13001706 / ISO 9001-QM-0090-13001706 / ISO 10002-CM-0090-13001706)
(Marka Patent No / Trademark)
$(2015 / 04018$ - 2015/GE/17595)

\section{INTRODUCTION}

It has already been acknowledged that buildings are responsible for about $40 \%$ of all energy consumption around the world, and this rate has been showing an increasing trend as buildings become more complex in response to the various comfort needs of the "users" (EIA, 2012:20; Y1lmaz, 2009:950-951). Today, civil and governmental authorities at both national and global scales are taking actions to reduce energy consumptions, and to control and minimize the adverse impacts on the environment (COM, 2006:3-6; Kibert, 2002: 379-394; Lee and Yik, 2002:251-253). One of the most important action came from the European Union (EU), which issued the Energy Performance in Buildings Directive (EPBD) (2002). The directive requires all member states to adopt their national calculation methods for the evaluation of energy performances of buildings. Accordingly, each and every government has re-organized its policies, laws, standards and regulations to define their methods.

Furthermore, the governments have been developing their own national assessment tools and labelling systems such as BREEAM in the United Kingdom, LEED in the United States, HK-BEAM in China, Green Star in Australia, DGNB in Germany, CASBEE in Japan, etc. to control the performance of buildings. The need to reduce the energy consumed by the buildings as well as all the environmental problems that are encountered more and more brings out the idea of performance based design in the architecture, which can be defined as a design optimization process regarding any imposed design criterion and heavily depends on the soft tools incorporated in the design process (Kolarevic, 2005:3). The use of such tools starting from the very early phases of the design process in an integrated way is expected to improve the convergence of the design to the design goal(s) i.e. performance (Çakıc1, 2013: 1-14).

One of the highly recognized design performance is the energy. Although there are several soft tools employed in the evaluation of building energy performances, their use and their integration to the design processes have certain difficulties which can be summarized as follows:

- The first is related with their structures and the database they use, in that each is developed by different countries for different regions and climatic conditions. Accordingly, each uses different building standards and calculation methods, and each makes different assumptions and defaults in the evaluations, limiting their validity.

- The second is the requirement of technical expertise in the field. Since these tools 


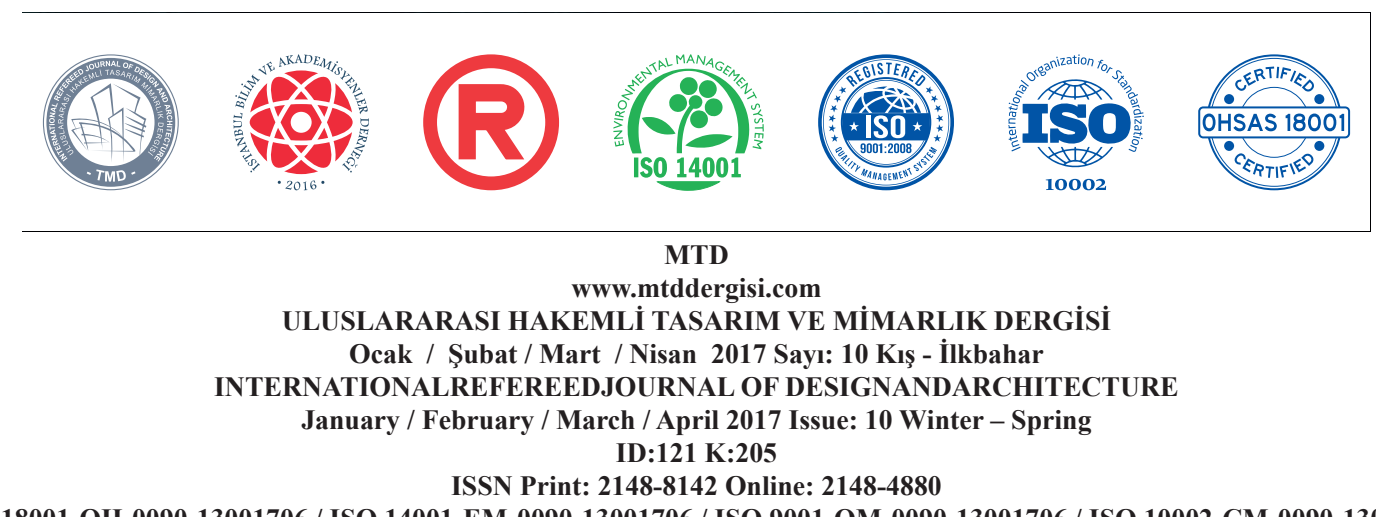

ISSN Print: 2148-8142 Online: 2148-4880
(ISO 18001-OH-0090-13001706 / ISO 14001-EM-0090-13001706 / ISO 9001-QM-0090-13001706 / ISO 10002-CM-0090-13001706)

(Marka Patent No / Trademark)

$(2015 / 04018-2015 / G E / 17595)$

have been developed primarily for use by engineers, they require very high level of technical knowledge on the subject.

- The third is the requirement of complex solid models; however, a 3D model of a building can mostly be developed in the late phases of the design process.

Moreover, the main focus of these tools is on performance evaluation rather than guiding the designer to support design decisions. However, they should be a part of the architectural design process, so as to improve the design and to achieve the desired performance goals in compliance with the local legislations, standards and database. In this regard, energy performance assessment tools should be re-designed to integrate a performance evaluation concept that can be applied throughout the entire architectural design process.

It is obvious that there is a need for decisionsupports tools, which can easily be used in every phases of the design process. In this context, to fill this gap in the literature, a building energy performance (BEP) evaluation program, entitled as Energy Performance Advisor (EnAd) is developed for evaluating the energy performance of buildings. EnAd is developed based on the requirements of the EPBD, TS EN ISO 137901 Thermal Performance of Buildings, the Turkish Regulation on Energy
Performance in Buildings (2008) and other related Turkish standards, laws and regulations. The monthly evaluation method proposed by TS EN ISO 13790 is employed in the analysis. In the scope of this research paper, after a brief introduction of the conceptual framework and structure of the program, validity, reliability, precision and usability of EnAd are explained, and the use of the program is exemplified with the help of a case study.

\section{EnAd as ENERGY PERFORMANCE EVALUATION TOOL}

Building performances especially energy performances can be evaluated by several programs and building information modelling (BIM) tools through complex 3D solid models, which can only be created towards the end of the design. There are about 400 building analysis software (As of February 2, 2016, Building Energy Software Tools Directory) for the evaluation of energy efficiency, renewable energy and sustainability in buildings listed on the official website of the US Department of Energy (DOE) ${ }^{2}$. A number of programs have been developed to carry out a building performance analyses on the entire building while others are intended to address a specific part of the building or process, or developed for code compliance. However, most tools require 3D model for the analysis, which can be created to the end of the design 


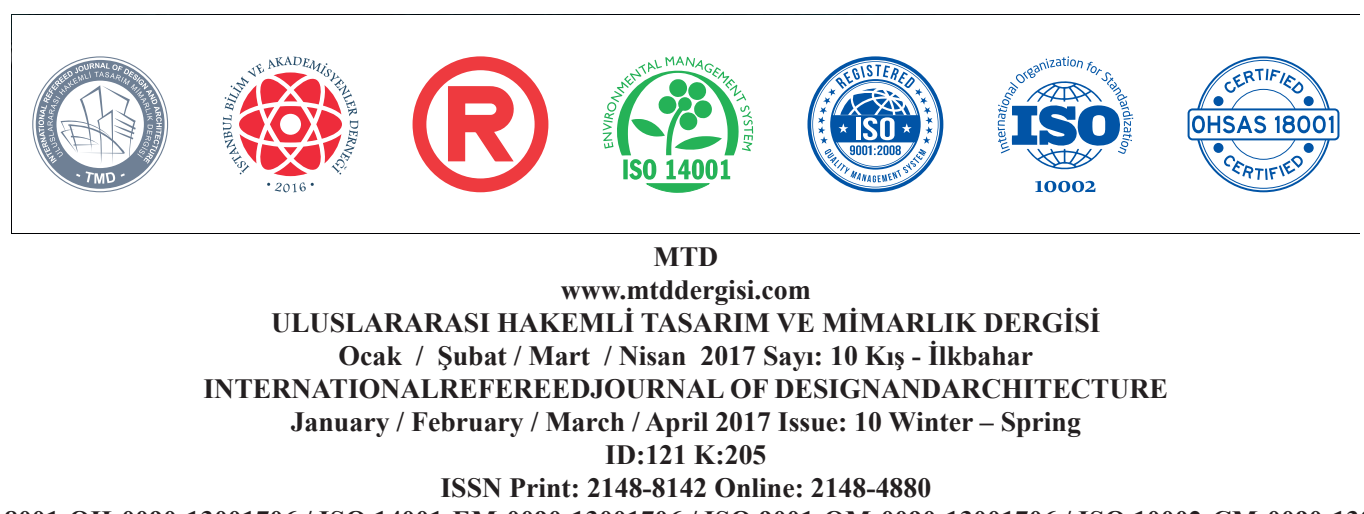

ISSN Print: 2148-8142 Online: 2148-4880

(ISO 18001-OH-0090-13001706 / ISO 14001-EM-0090-13001706 / ISO 9001-QM-0090-13001706 / ISO 10002-CM-0090-13001706)

(Marka Patent No / Trademark)

$(2015 / 04018-2015 / G E / 17595)$

when it becomes difficult to change design decisions.

The most crucial decisions affecting the energy performance are taken in the predesign and design phases, including orientation, building envelope, window/wall ratio, form and material properties etc. In this respect, these soft tools should be capable of being used in entire design process even in the pre-design. EnAd, being a computer program, aims to fill this gap and designed to support the architect throughout the design process. The tool is capable of computing monthly and annual energy requirements of a building for heating, cooling, domestic hot water (DHW) and lighting, and assesses the building's energy performance through evaluations while providing feedback to improve the design. To use this program, it is not necessary to complete the project, or even to have a project at all. Another significant feature of EnAd is that, it features a flexible user-friendly interface (Figure 1) that does not require any advanced expertise.

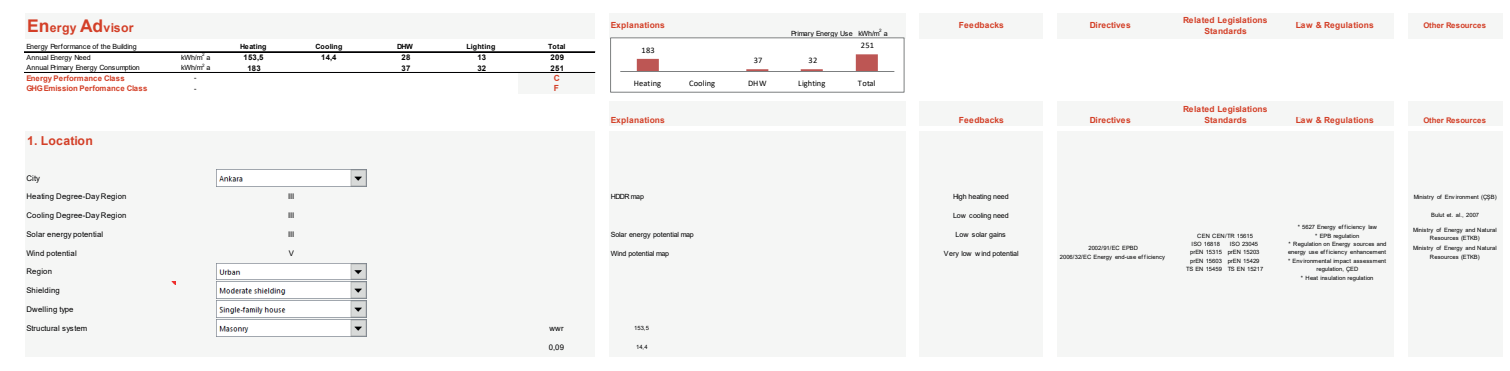

Figure 1. EnAd User Interface for Data Inputs

EnAd uses Turkish (TS and TS ISO) standards, laws and regulations to determine the constraints and objectives of the design "guides" designers for energy-conscious design, but also serves as a "diagnostic tool," determining inconsistencies/deficiencies in the legal framework. Thus EnAd can be considered as a design and evaluation interface, providing a schema for performance-based design, having performance objectives and constraints derived from the legislations and standards. EnAd is also intended to motivate users to re-think the building design process, considering energy as the performance criterion. The objectives for the program are as follows:

- To operate as an evaluation tool for the assessment of the energy performance of buildings that can be used even in the early phases of the design process.

- To help the designer determine the level of energy performance at any stage of the design process, which will be shown on 


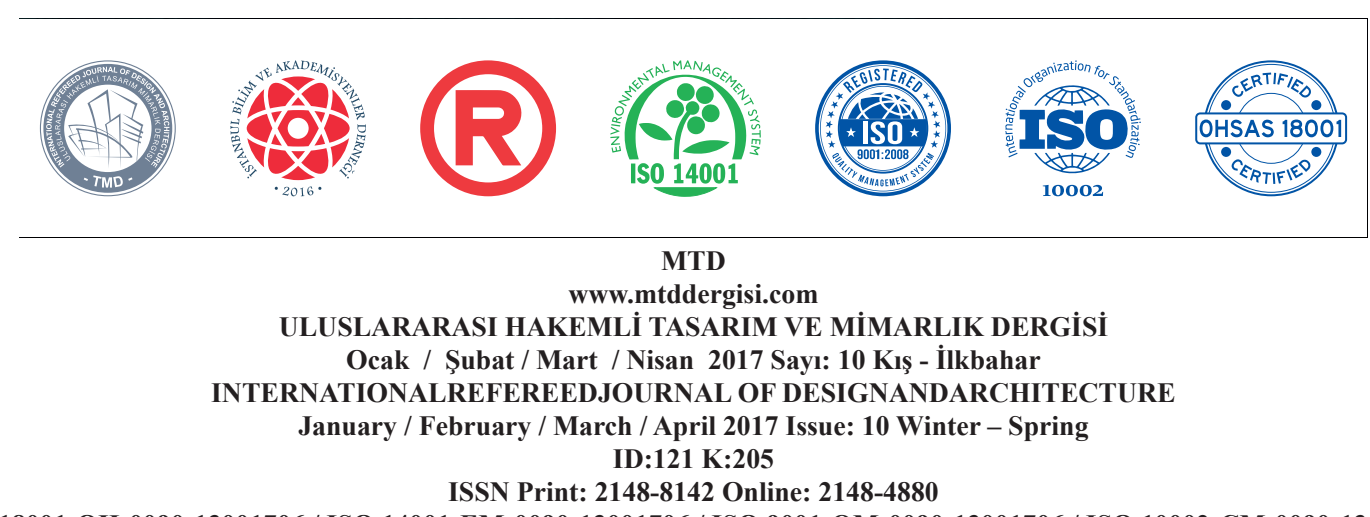

ISSN Print: 2148-8142 Online: 2148-4880
(ISO 18001-OH-0090-13001706 / ISO 14001-EM-0090-13001706 / ISO 9001-QM-0090-13001706 / ISO 10002-CM-0090-13001706)

(Marka Patent No / Trademark)

$(2015 / 04018-2015 / G E / 17595)$

the energy performance certificate of the building.

- To be flexible and easy to use.

- To be used recursively in the design of new buildings as well as in retrofitting practices.

- To guide the designer towards achieving higher energy performances with the help of explanations related to design decisions and feedback, both on legislation and the design decisions made for each step, if possible.

- To evaluate the energy requirements, energy consumption, primary energy need, and accordingly, $\mathrm{CO}_{2}$ emissions of a building.

- To help design buildings with high energy performance and low $\mathrm{CO}_{2}$ emissions.
- To assess the energy performance class and greenhouse gas (GHG) emission class according to consumption data.

\section{Program Structure of EnAd}

EnAd is a soft tool for the evaluation of the energy performance of residential buildings considering the energy requirements for the four energy parameters: space heating, cooling, domestic hot water and artificial lighting. Heat transfer calculations within EnAd are derived based on EPBD, Turkish BEP Regulation and the related standards and documents. The general program structure of EnAd is illustrated in Figure 2. As in many other evaluation programs, EnAd requires the selection of location or weather data, building form, material properties, and options for service systems with a schedule of use. 


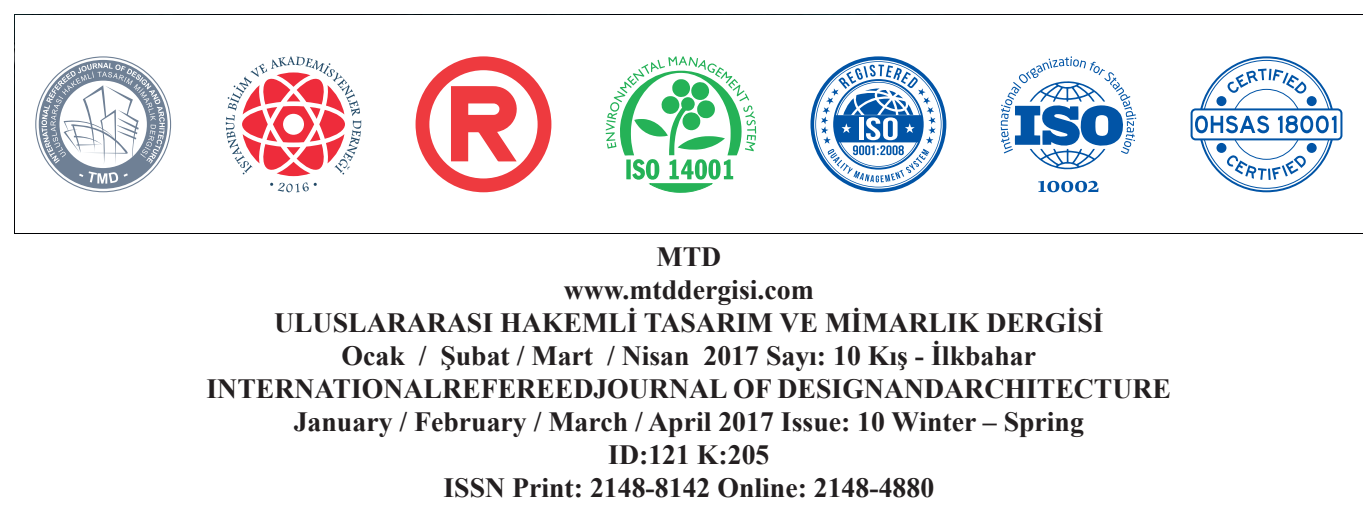

(ISO 18001-OH-0090-13001706 / ISO 14001-EM-0090-13001706 / ISO 9001-QM-0090-13001706 / ISO 10002-CM-0090-13001706)

(Marka Patent No / Trademark)

$(2015 / 04018-2015 / G E / 17595)$

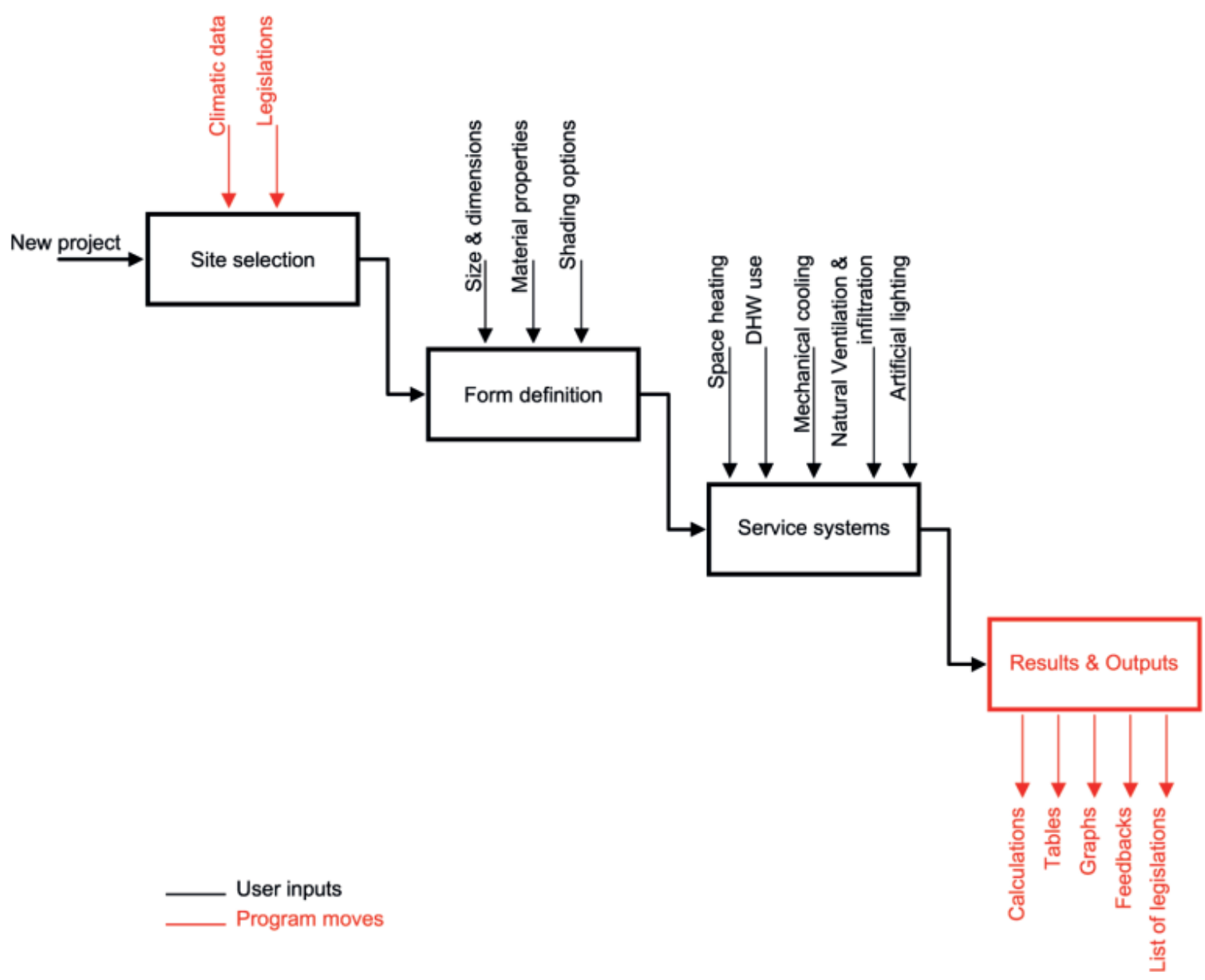

Figure 2. Program Structure of EnAd

\section{Data Structure of EnAd}

In EnAd, design decisions and factors affecting the energy performance of buildings defined by TS EN $15217^{3}$, including thermal characteristics of buildings, space heating, domestic hot water supply, air conditioning, ventilation, lighting, passive solar heat sources, solar protection and energy production; and TS $825^{4}$, including thermal characteris- tics of the building, types of heating system, indoor air quality, climatic conditions, inner heat gain resources and solar radiation form the bases of the tool.

These decisions and factors are taken into consideration to produce an outline that will form the conceptual structure of EnAd, which suggests investigating them under four main headings: 


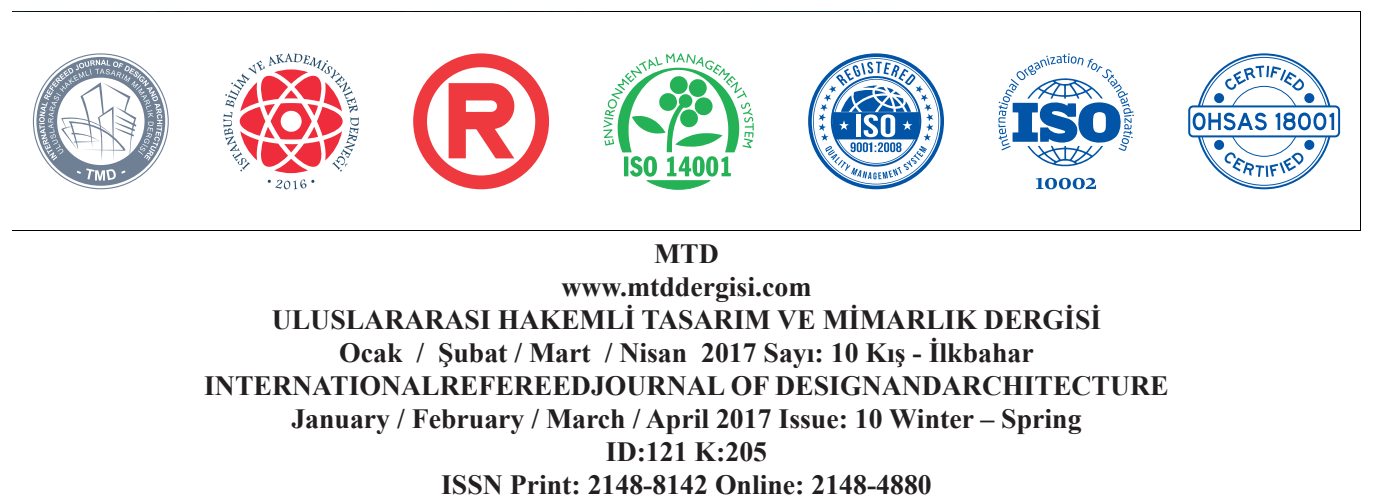

(ISO 18001-OH-0090-13001706 / ISO 14001-EM-0090-13001706 / ISO 9001-QM-0090-13001706 / ISO 10002-CM-0090-13001706)

(Marka Patent No / Trademark)

$(2015 / 04018-2015 / G E / 17595)$

- Site-related characteristics: Location

- Form-related decisions: Definition of the building form

\section{- Construction-related decisions:}

Properties of the building envelope

- Energy-related decisions: Building systems
The second step of the development process of EnAd is to investigate the relationship between design decisions and factors affecting the energy requirement of buildings and legislation, which includes directives, standards, laws and regulations. To this end, the Turkish legislation regarding the energy performance of buildings is reviewed and grouped according to the design decisions as shown in Figure 3. 


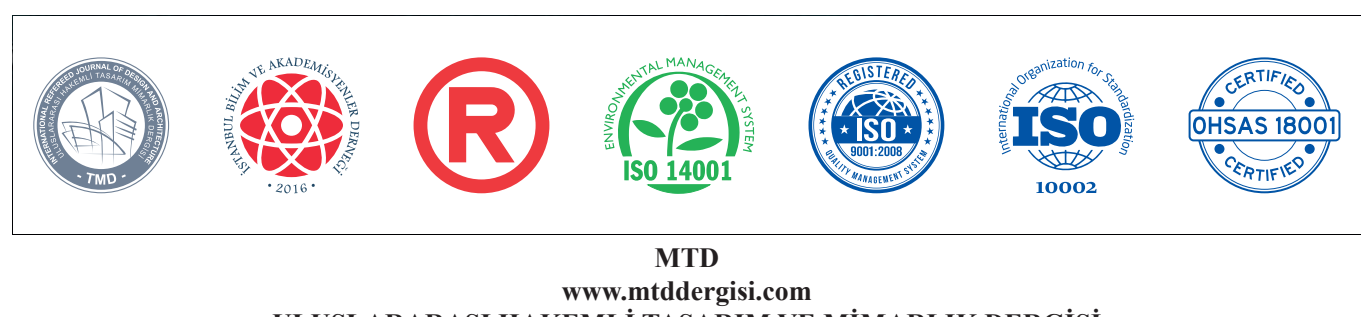

ULUSLARARASI HAKEMLİ TASARIM VE MIMARLIK DERGISİ

Ocak / Şubat / Mart / Nisan 2017 Sayı: 10 Kış - İlkbahar

INTERNATIONALREFEREEDJOURNAL OF DESIGNANDARCHITECTURE

January / February / March / April 2017 Issue: 10 Winter - Spring ID:121 K:205

ISSN Print: 2148-8142 Online: 2148-4880

(ISO 18001-OH-0090-13001706 / ISO 14001-EM-0090-13001706 / ISO 9001-QM-0090-13001706 / ISO 10002-CM-0090-13001706)

(Marka Patent No / Trademark)

$(2015 / 04018-2015 / G E / 17595)$

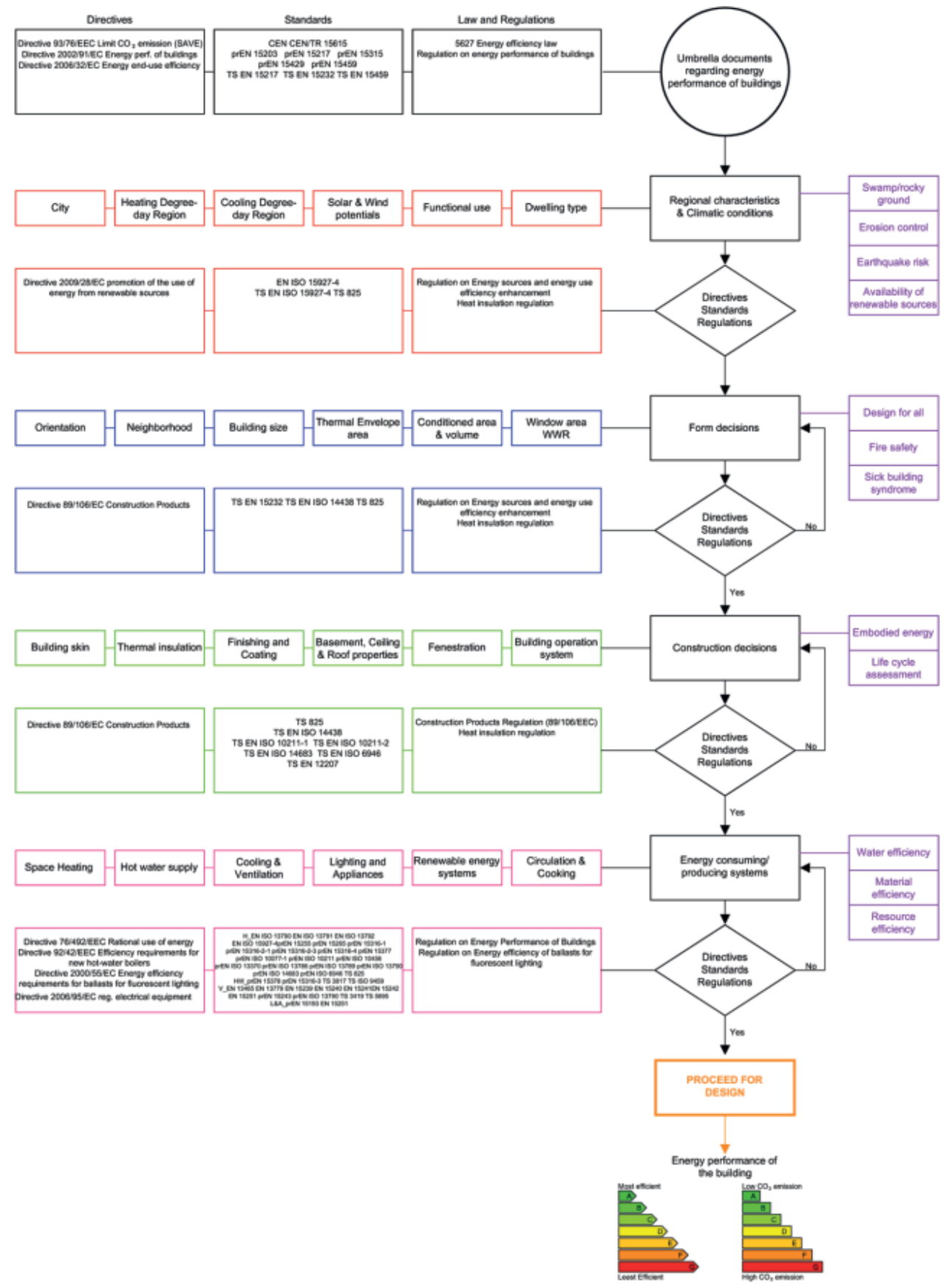

Figure 3. Flowchart Showing the Design Decisions in Relation to Turkish Legislation 


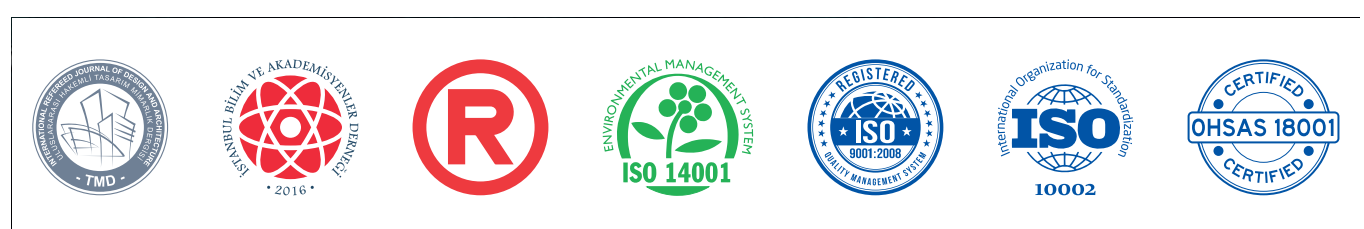

MTD

www.mtddergisi.com

ULUSLARARASI HAKEMLİ TASARIM VE MIMARLIK DERGÍSI

Ocak / Şubat / Mart / Nisan 2017 Sayı: 10 Kış - İlkbahar

INTERNATIONALREFEREEDJOURNAL OF DESIGNANDARCHITECTURE

January / February / March / April 2017 Issue: 10 Winter - Spring

ID:121 K:205

ISSN Print: 2148-8142 Online: 2148-4880

(ISO 18001-OH-0090-13001706 / ISO 14001-EM-0090-13001706 / ISO 9001-QM-0090-13001706 / ISO 10002-CM-0090-13001706)

(Marka Patent No / Trademark)

$(2015 / 04018-2015 / G E / 17595)$

In EnAd, for the energy used in space heating and cooling, the monthly calculation method based on TS EN ISO 13790 is preferred. The reason is that, although the simple hourly method makes a comparison of hourly changes in the building, the monthly method is accepted to give more reliable and accurate results for annual calculations. Furthermore, the simple hourly method is based on direct calculations and the results cannot be controlled by the user; whereas the monthly method offers to use convergence coefficients, allowing the control of subsequent calculations in the evaluations ${ }^{1}$.

\section{Data Handling and Decision Making}

The program requires the uploading of input data, which are directly related with the design decisions. According to the location selected, the program automatically provides a reference building, on which the designer is informed with related legislations, standards as well as can observe how the decisions evolve the design affecting the performance. EnAd provides feedback through the reference building, showing the objectives/constraints as described by the legislations, standards and etc. The program calculates the energy need, evaluates the energy performance, and makes an assessment of the energy performance class of the building by comparing the results with the reference building and the improved case. If the user follows the feedback provided, s/he can improve the design in terms of optimum energy performance. The data flow and general structure of the program is presented in Figure 5. 


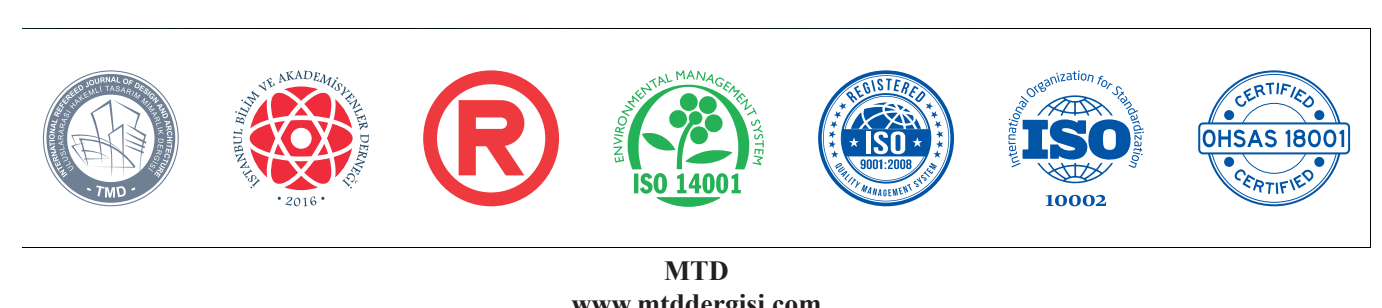

www.mtddergisi.com

ULUSLARARASI HAKEMLI TASARIM VE MIMARLIK DERGISI

Ocak / Şubat / Mart / Nisan 2017 Sayı: 10 Kış - İlkbahar

INTERNATIONALREFEREEDJOURNAL OF DESIGNANDARCHITECTURE

January / February / March / April 2017 Issue: 10 Winter - Spring ID:121 K:205

ISSN Print: 2148-8142 Online: 2148-4880

(ISO 18001-OH-0090-13001706 / ISO 14001-EM-0090-13001706 / ISO 9001-QM-0090-13001706 / ISO 10002-CM-0090-13001706)

(Marka Patent No / Trademark)

$(2015 / 04018-2015 / G E / 17595)$

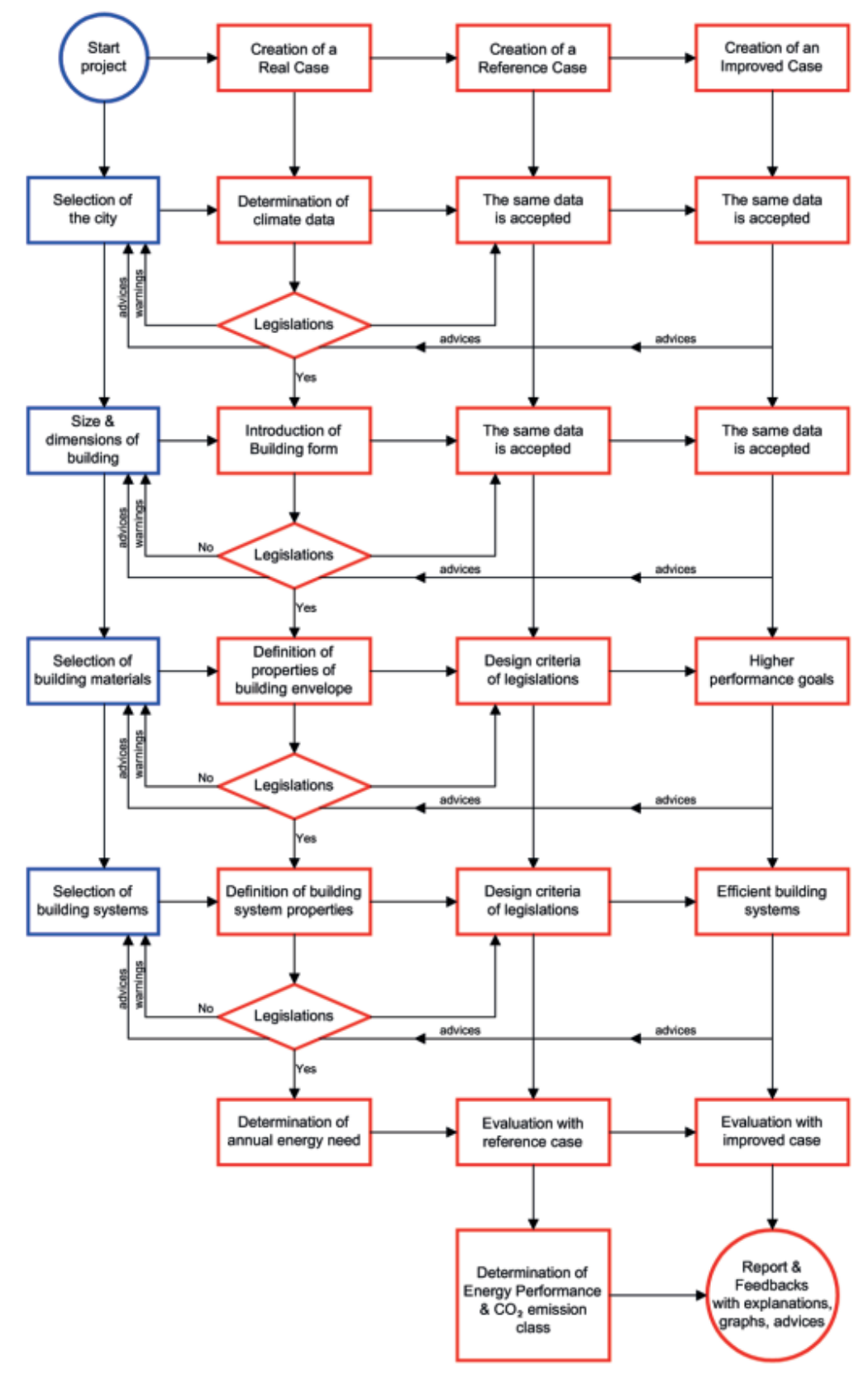

Operations of the Program

Inputs by the User

Figure 5. Data Handling and Decision Making in the Program 

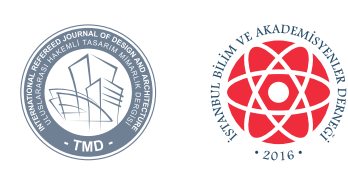

MTD

www.mtddergisi.com

ULUSLARARASI HAKEMLİ TASARIM VE MIMARLIK DERGİSì

Ocak / Şubat / Mart / Nisan 2017 Sayı: 10 Kış - İlkbahar

INTERNATIONALREFEREEDJOURNAL OF DESIGNANDARCHITECTURE

January / February / March / April 2017 Issue: 10 Winter - Spring ID:121 K:205

ISSN Print: 2148-8142 Online: 2148-4880

(ISO 18001-OH-0090-13001706 / ISO 14001-EM-0090-13001706 / ISO 9001-QM-0090-13001706 / ISO 10002-CM-0090-13001706)

(Marka Patent No / Trademark)

(2015/04018 - 2015/GE/17595)

\section{Input and Outputs}

The program interface comprises the following parts:

- Data input page, which is the main screen of the program, and includes data inputs, explanations, feedbacks and the legislations related to the design decisions.

- Weather data page, presenting the climatic data for 81 cities of Turkey, and allowing the addition of data for new cities,

- Calculations page, providing the tables and graphs showing the calculation steps of the evaluation,

- Results page, presenting the results of the energy performance evaluation of the building, and

- Feedback page, providing feedback related to the design.

The interface layout of the data input sheet is presented in Figure 6.

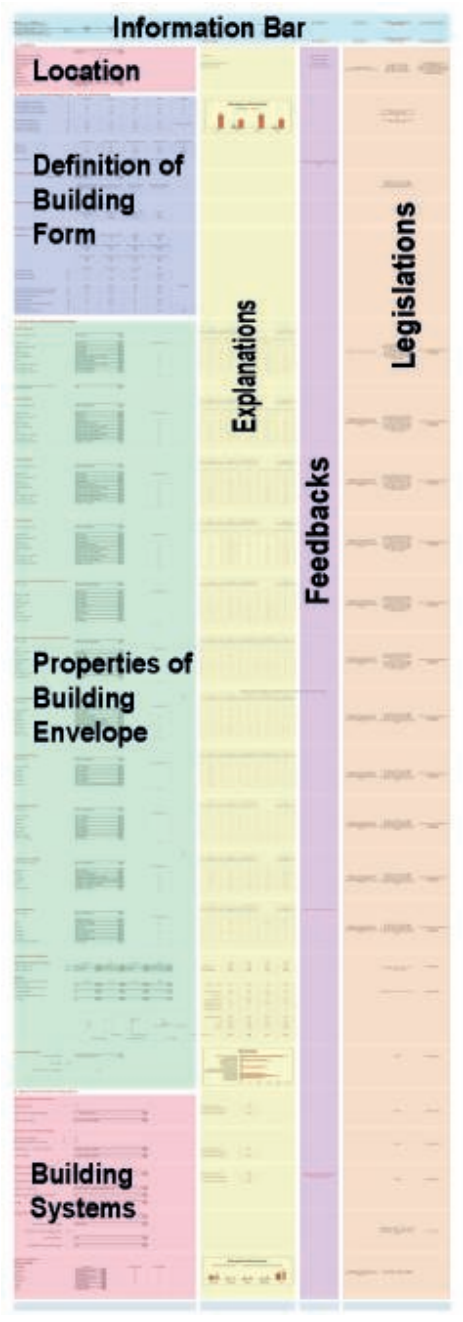

\section{Figure 6. Interface Layout of the Data Input Sheet}

The location input requires an evaluation of the climatic conditions and immediate surroundings of the building (Figure 7). According to the location selected, the tool presents data and feedback related to the city selected, which helps to define the limit values for the city based on current legislation. 


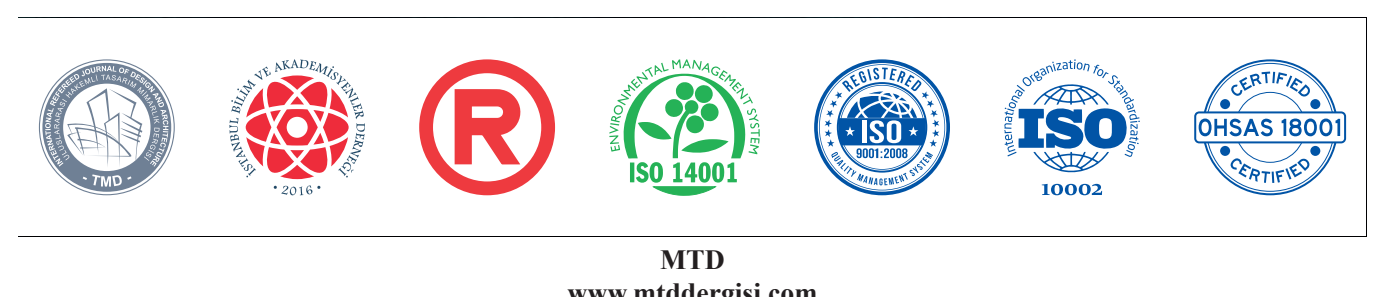

www.mtddergisi.com

ULUSLARARASI HAKEMLI TASARIM VE MIMAARLIK DERGISİ

Ocak / Şubat / Mart / Nisan 2017 Sayı: 10 Kış - İlkbahar

INTERNATIONALREFEREEDJOURNAL OF DESIGNANDARCHITECTURE

January / February / March / April 2017 Issue: 10 Winter - Spring

ID:121 K:205

ISSN Print: 2148-8142 Online: 2148-4880

(ISO 18001-OH-0090-13001706 / ISO 14001-EM-0090-13001706 / ISO 9001-QM-0090-13001706 / ISO 10002-CM-0090-13001706)

(Marka Patent No / Trademark)

$(2015 / 04018-2015 / G E / 17595)$

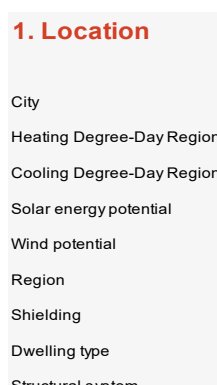

Structural system

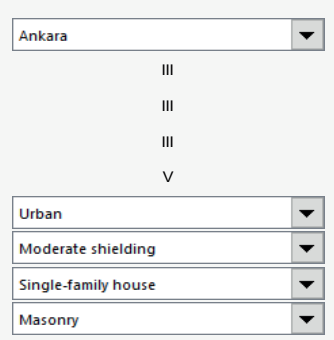

HDDR map

Solar energy potential map

Wind potential map

Figure 7. Example of Input Data for Location

The second step of data inputs is the definition also defined in this step as well. According to of the building form. Considering the orien- the data provided, the program calculates the tation of the building, the dimensions of each construction area, the conditioned area and façade and window are entered for different volume, the thermal envelope area and comtypes of floors as shown in Figure 8. The ge- pactness ratio, etc.

neral properties of the basement and roof are

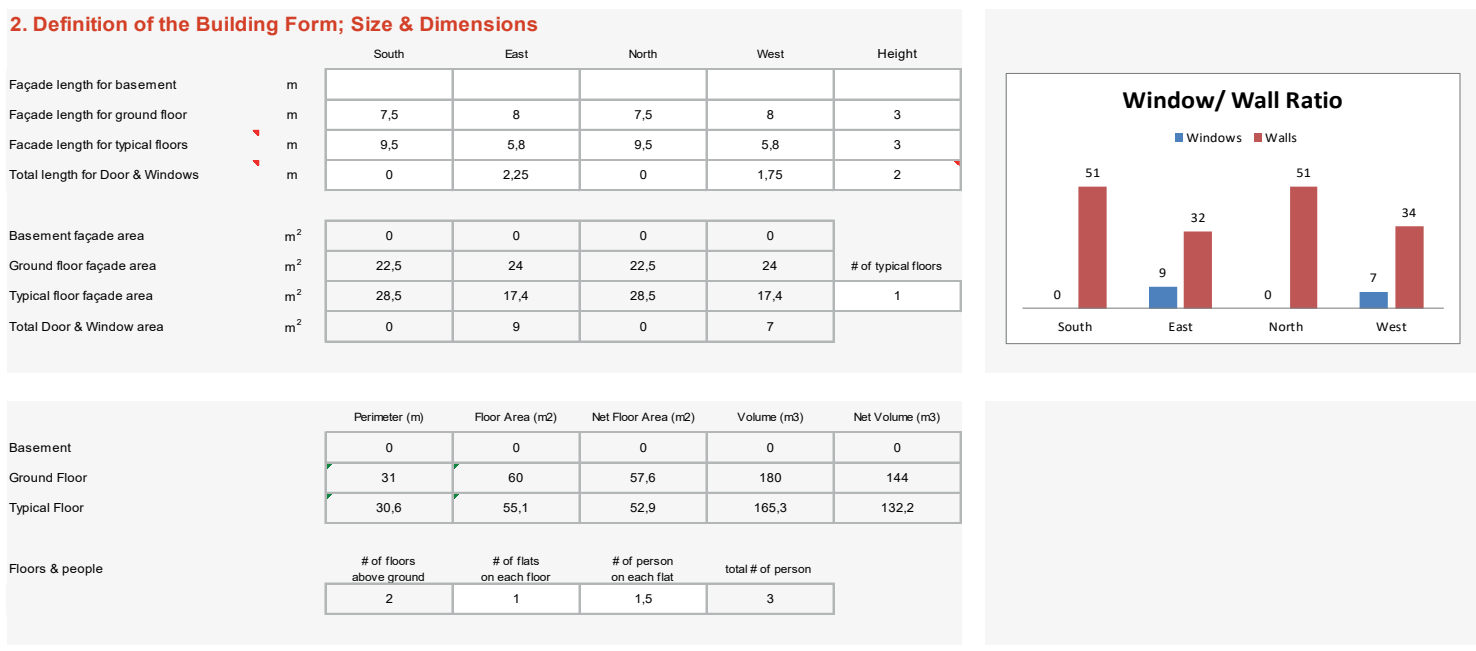

Figure 8. Data Input Example for Form Definition 


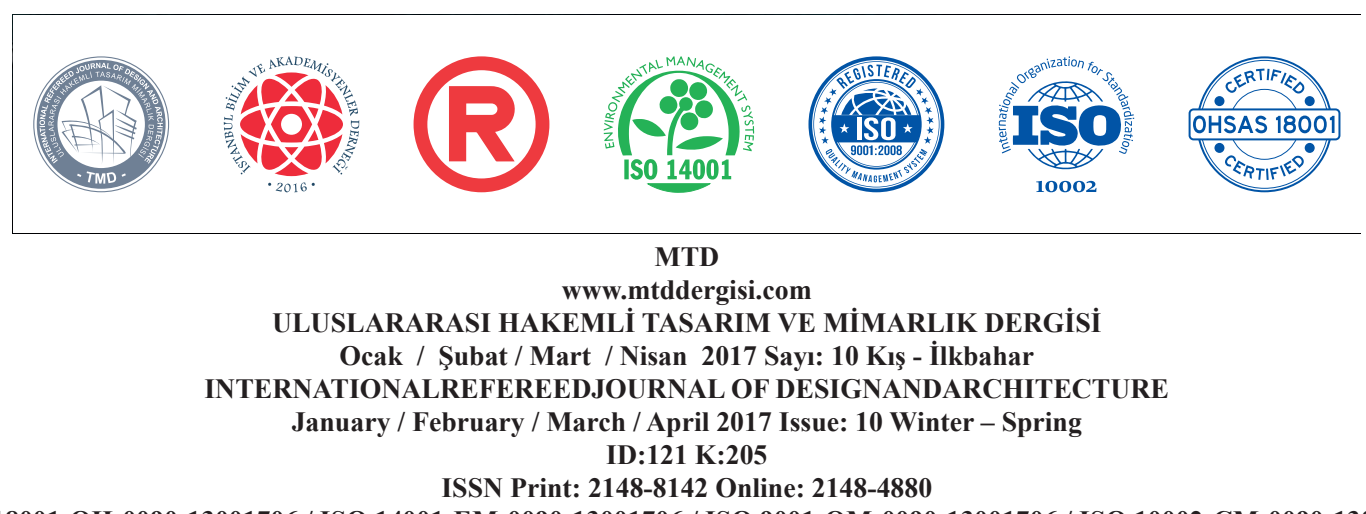

ISSN Print: 2148-8142 Online: 2148-4880

(ISO 18001-OH-0090-13001706 / ISO 14001-EM-0090-13001706 / ISO 9001-QM-0090-13001706 / ISO 10002-CM-0090-13001706)

(Marka Patent No / Trademark)

$(2015 / 04018-2015 /$ GE/17595)

The properties of the building envelope are determined in the third step (Figure 9). Since EnAd has been developed especially for use by architects, paramount importance is given to design decisions. For this reason, unlike the other tools, which prioritize the mechanical systems, the main focus of this tool is on the pre-design phase. The program allows a definition of the properties of all surfaces of the building envelope, including the four façades, the below-ground basement walls earth and above-ground walls, the ground floor, the basement floor, any cantilever floors, ceilings or flat roofs, inclined roofs, windows and doors. Several options are provided in the program for each surface, such as default construction type, the manual definition of layers, as well as adjacency to conditioned or unconditioned spaces and interior surfaces. As shown in Figure 9, the user can select different material layers from editable dropdown menus provided for each material. Options for windows and shading are also defined in this step in the program, including single, double and triple glazing with different types of window frames.
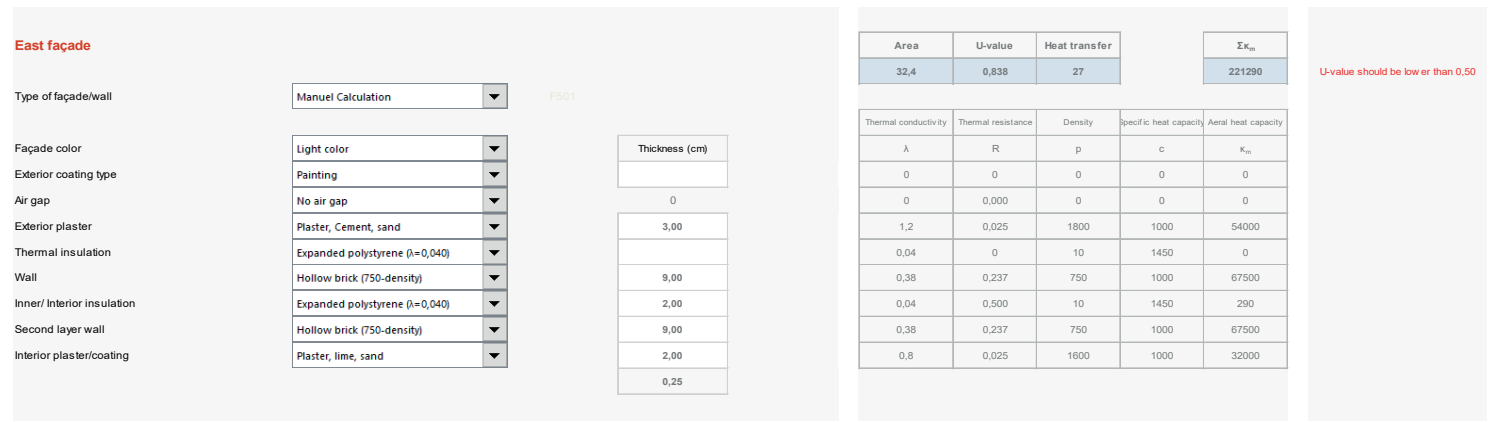

Figure 9. Definition of Properties of the Building Envelope

The final step in the data input phase is the determination of the natural and mechanical systems used in the building. Contrary to many other tools, this phase is kept brief, since the tool has not been developed for system design or sizing. The primary goal of such an informative step is to give the designer an idea of building systems, and their approximate effects on the results, and in turn, on the energy performance of buildings.
The program provides several options for space heating, mechanical cooling and water heating systems (Figure 10). The space heating systems include community heating systems, central heating systems, warm air systems, room heaters, electric under-floor heating, electric ceiling heating and air conditioners. The list of cooling equipment consists of three types of air conditioner with ten energy efficiency classes, as described in EU 


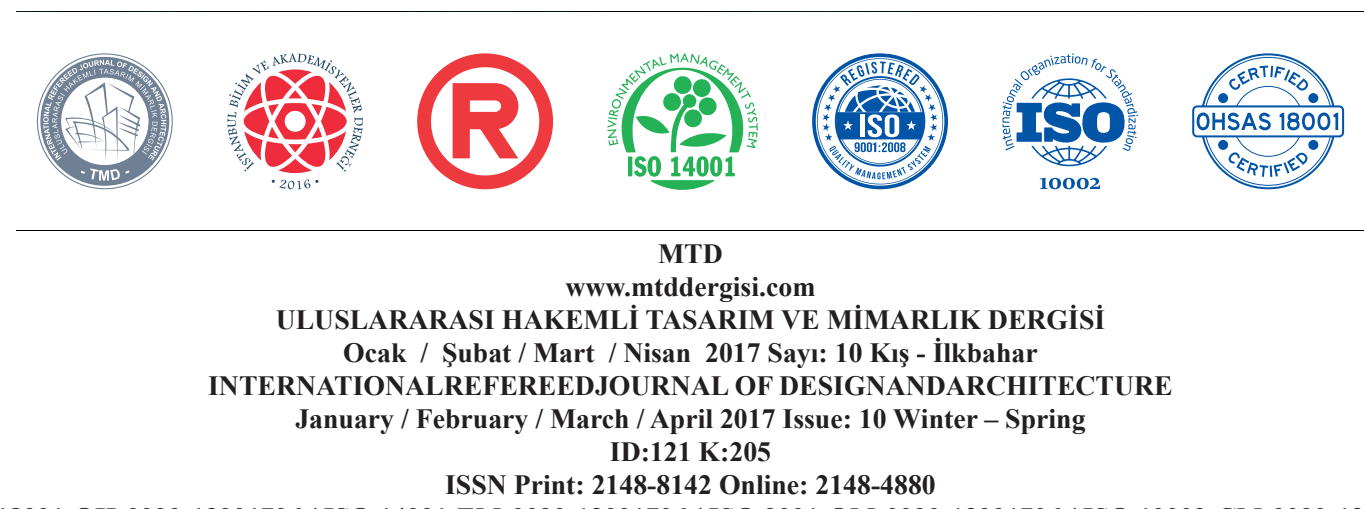

ISSN Print: 2148-8142 Online: 2148-4880
(ISO 18001-OH-0090-13001706 / ISO 14001-EM-0090-13001706 / ISO 9001-QM-0090-13001706 / ISO 10002-CM-0090-13001706)

(Marka Patent No / Trademark)

$(2015 / 04018-2015 / G E / 17595)$

Directive 2010/30. The water heating equipment can be selected from among stand-alone water heaters, or it can be provided by space heating system if required. The user can also define the properties of natural ventilation and mechanical ventilation in EnAd. Similar to ventilation, infiltration, which can be defined as the airtightness level of the building envelope, can be activated or deactivated in the evaluations. The last step in the data input phase is the definition of artificial lighting.
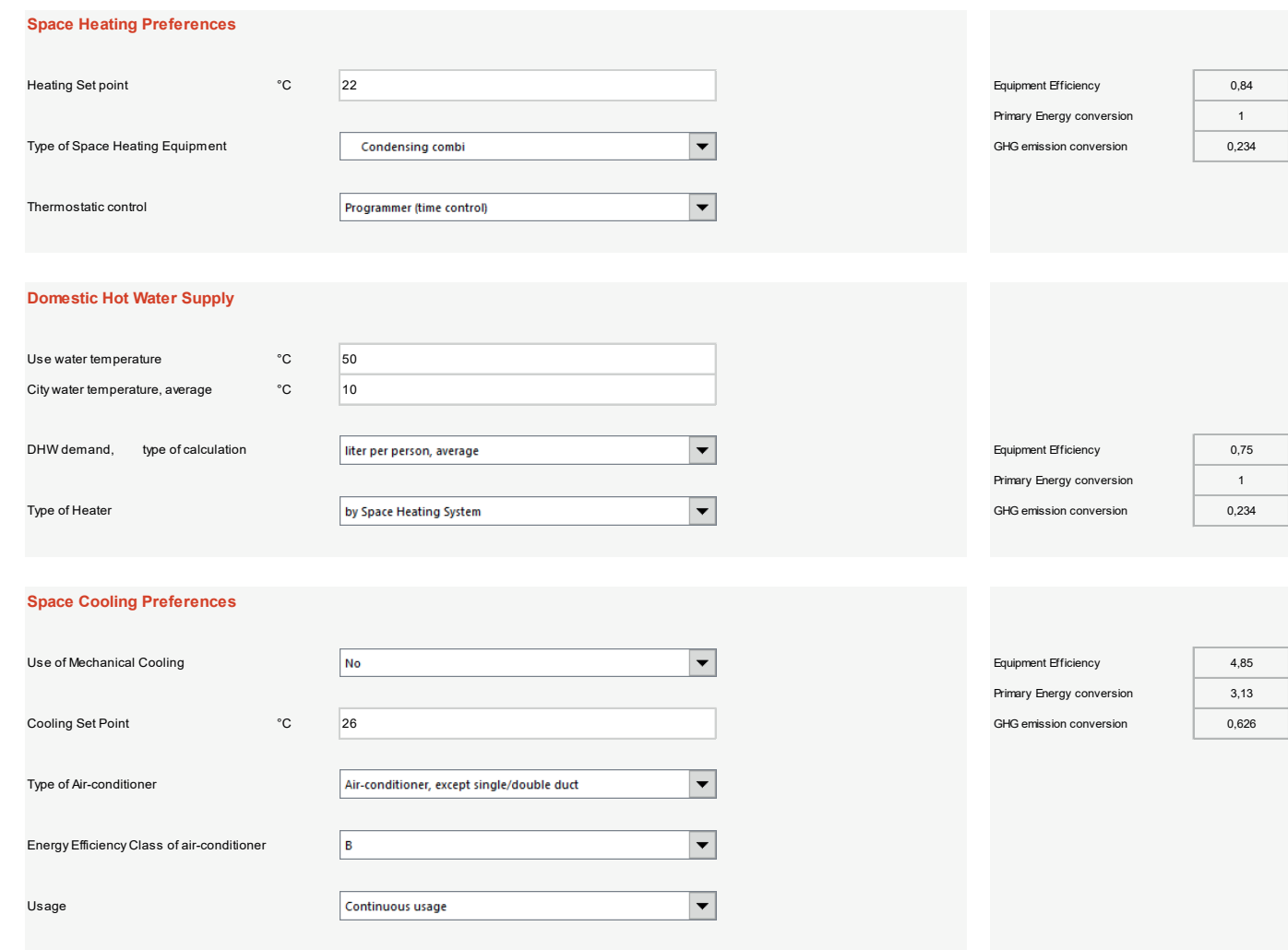

Figure 10. Definition of Properties of Building Systems

In order to maintain flexibility and speed when using EnAd, four output groups are provided by the program: quick results, shown on the data input sheet, as well as calculations, results and feedback. Since the program has been developed to be informative and to raise the consciousness of the designers, the quick results on the input page have great significance, aiming to provide feedback information that relates to the design decisions and performance goals, from which the user is expected to adjust her/his decisions accordingly. The quick results include an 'information bar', 'explanations, 'feedback', 'related 


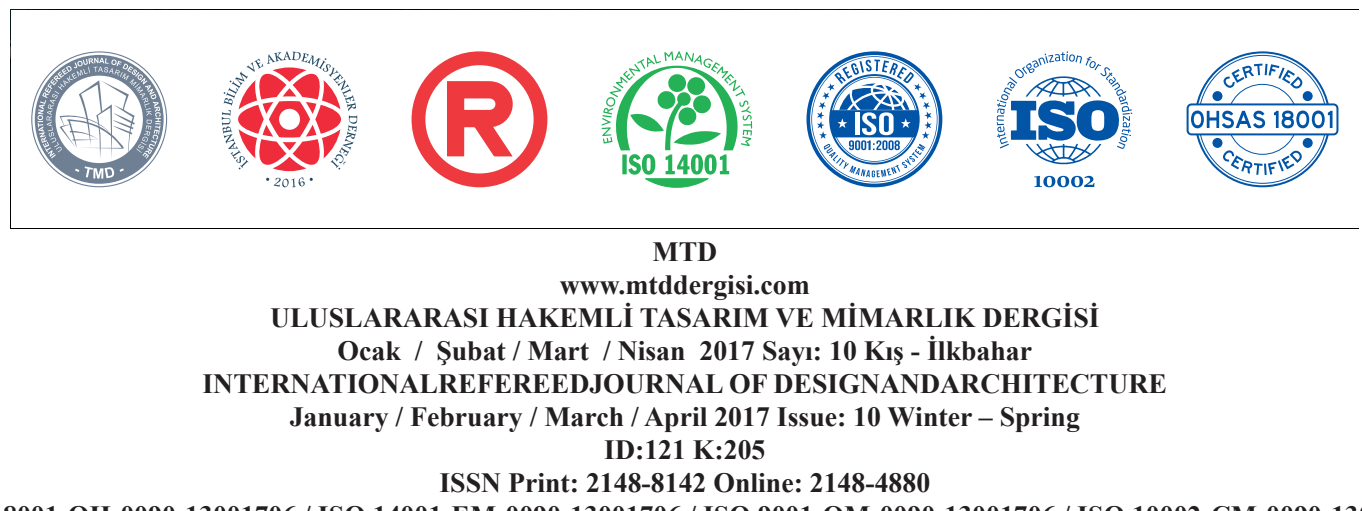

ISSN Print: 2148-8142 Online: 2148-4880

(ISO 18001-OH-0090-13001706 / ISO 14001-EM-0090-13001706 / ISO 9001-QM-0090-13001706 / ISO 10002-CM-0090-13001706)

(Marka Patent No / Trademark)

$(2015 / 04018-2015 / G E / 17595)$

legislation' and 'other resources'. The interface features an information bar at the top of the data input screen, which shows the annual energy requirement and primary energy use for heating, cooling, DHW and lighting, as well as the energy performance class and GHG emission class of the building (Figure 11). The explanations section provides maps, tables and graphs to summarize and illustrate the current situation; while the feedback part provides information and warnings related to the performance goals to be achieved. These quick outputs are updated after each change in the design, and show the effects of each decision on the results.

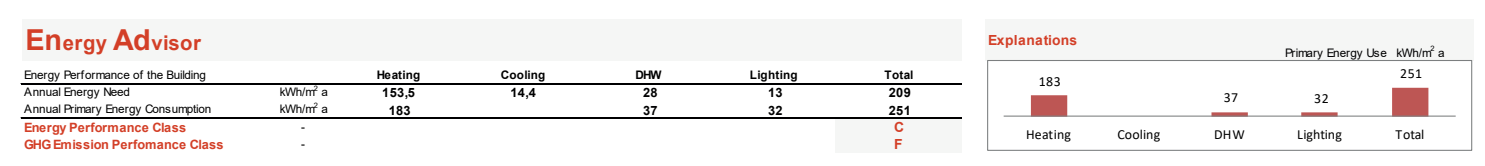

Figure 11. Information Bar at the Top of the Input Page

The second type of output provided by the program is the Calculations. The user can follow the calculation steps and the intermediate steps of the evaluation, as well as the monthly results in detail. The Results page is not as technical as the calculations section, as its function is to present a summary of the calculations. One of the most important outputs in the results is the indication of performance classes. As shown in Figure 12, the results sheet presents the energy performance class and GHG emissions class of the original building, the reference building and the improved case, as well as A and G limits of the legislation in both table and graphical forms. These performance tables and graphs notify the user of the status of the design and give indicates suggested actions for the achievement of better results. 


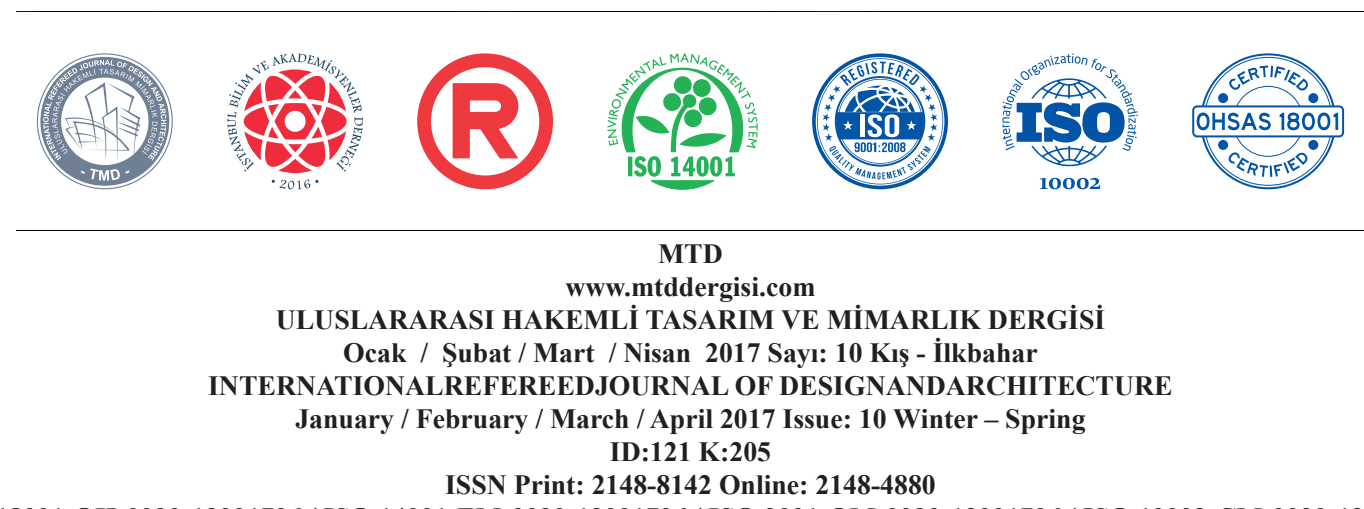

ISSN Print: 2148-8142 Online: 2148-4880

(ISO 18001-OH-0090-13001706 / ISO 14001-EM-0090-13001706 / ISO 9001-QM-0090-13001706 / ISO 10002-CM-0090-13001706)

(Marka Patent No / Trademark)

$(2015 / 04018-2015 / G E / 17595)$
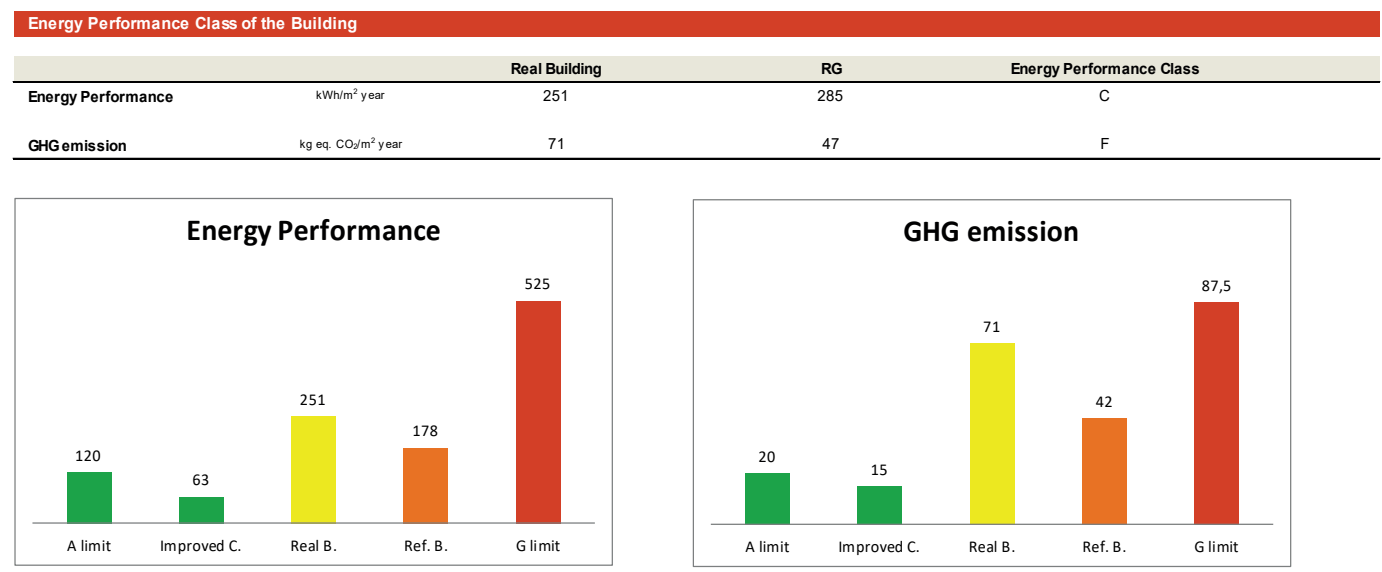

Figure 12. Presentation of Performance Class of the Building

The Results sheet also presents the monthly and annual energy requirements, the energy use and the primary energy requirement for heating, cooling, DHW and lighting. Although results for each unit are preferred to permit ease in comparison, the results are provided for both the entire building and for each unit. The monthly and annual results are presented as both tabulated numerical outputs and graphical outputs, as presented in Figure 13.

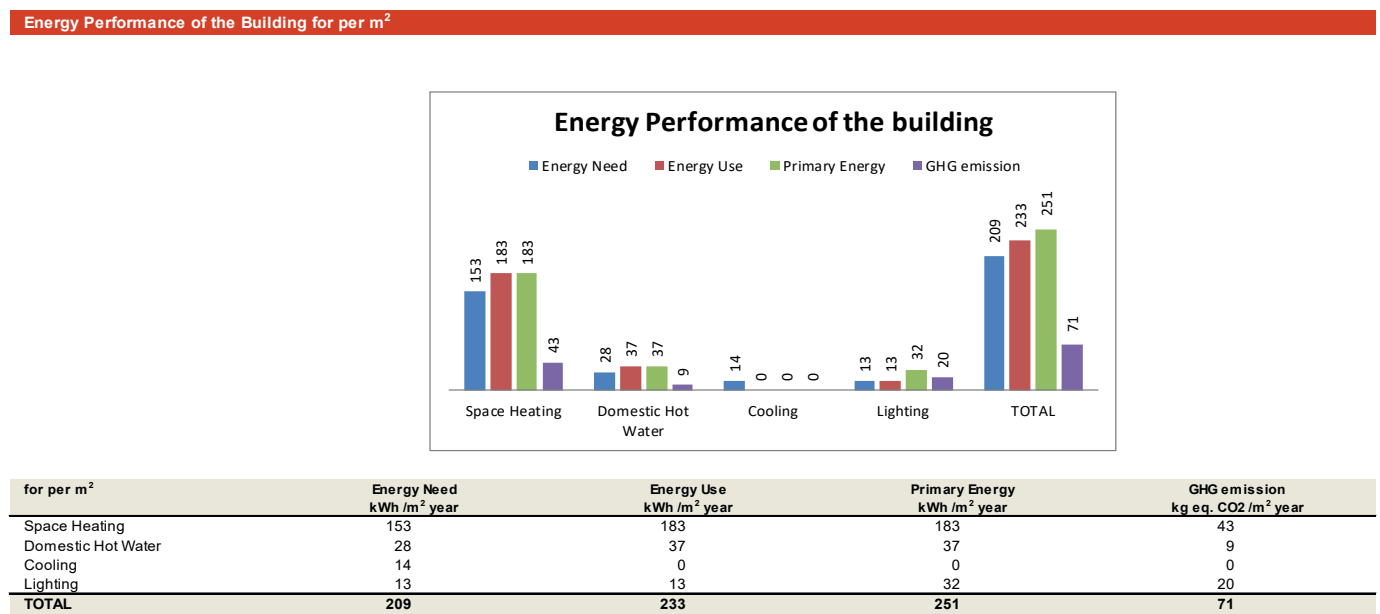

Figure 13. Presentation of Energy Performance of the Building per Unit 


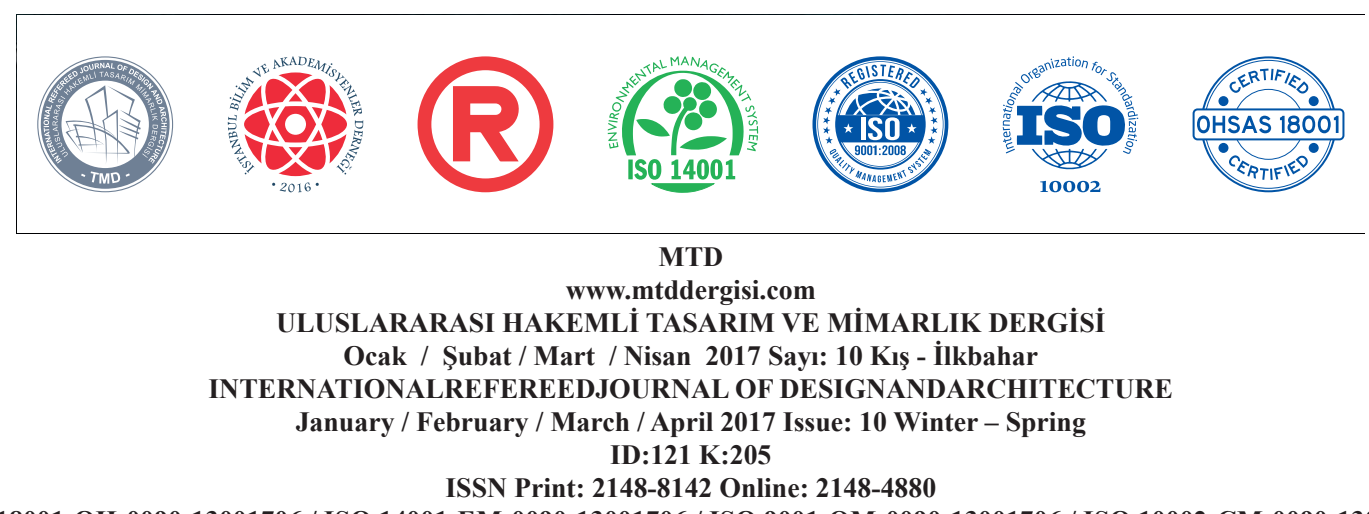

(ISO 18001-OH-0090-13001706 / ISO 14001-EM-0090-13001706 / ISO 9001-QM-0090-13001706 / ISO 10002-CM-0090-13001706)

(Marka Patent No / Trademark)

$(2015 / 04018-2015 / G E / 17595)$

The most important output provided by the program is the Feedback, which is compiled and presented on the feedback page in tabular form, and also on the data input sheet to facilitate design decisions. The feedback page provides summary information about the design decisions, making a comparison with the performance criteria defined in a provided list of legislation, and making recommendations related to the decisions.

\section{USABILITY, VALIDITY, RELIABILITY and PRECISION of EnAd}

\section{Validity, Reliability and Precision of EnAd}

As in many other evaluation tools, the validity, reliability range and precision of EnAd is explored in detail through several case studies including a reference case that is the worked example in TS EN ISO 13790; generic cases, in which the major features of buildings affecting energy performance are studied in order to observe the validity of EnAd; and existing building projects for which the energy consumption data is known so as to observe the convergence of the results of EnAd with those of the other programs.

For comparative studies, three different BEP evaluation tools are selected: DesignBuilder, which is a comprehensive simulation tool with embedded CAD modelling and a rich library; HAP, which is a text-based simulation tool used for the design of HVAC systems; and EnerCalc, which is a calculation tool based on German standards. These three programs, developed by different countries and using different methods of calculation, are internationally acknowledged for their accuracy. Around 150 generic cases are developed by changing one feature for each step to examine the effect of each parameter/assumption on the results. For the benchmarking study, one existing building is assessed by the tools.

Considering the results obtained from all generic cases including extreme conditions as well, 156 in total, evaluated by the four programs, the precision and reliability of EnAd in the calculation of heating, cooling, lighting and DHW requirements is proven. It can be noted that EnAd gives consistent results in itself and for many cases gives average results for energy requirements for heating, cooling, DHW and lighting.

The convergence of the results is shown in Table 1. As can be seen from Table 1, the convergence of the results of EnAd with respect to those of DesignBuilder, HAP and EnerCalc for heating is found to be between $-18-5 \%$, for cooling between $-22-8 \%$, for DHW between $-28-9 \%$, and for lighting between -8 $-17 \%$. These discrepancies in the results can be attributed to the different energy models and calculation methods employed by the four programs, and also differences both in the data input and the databases used by the 


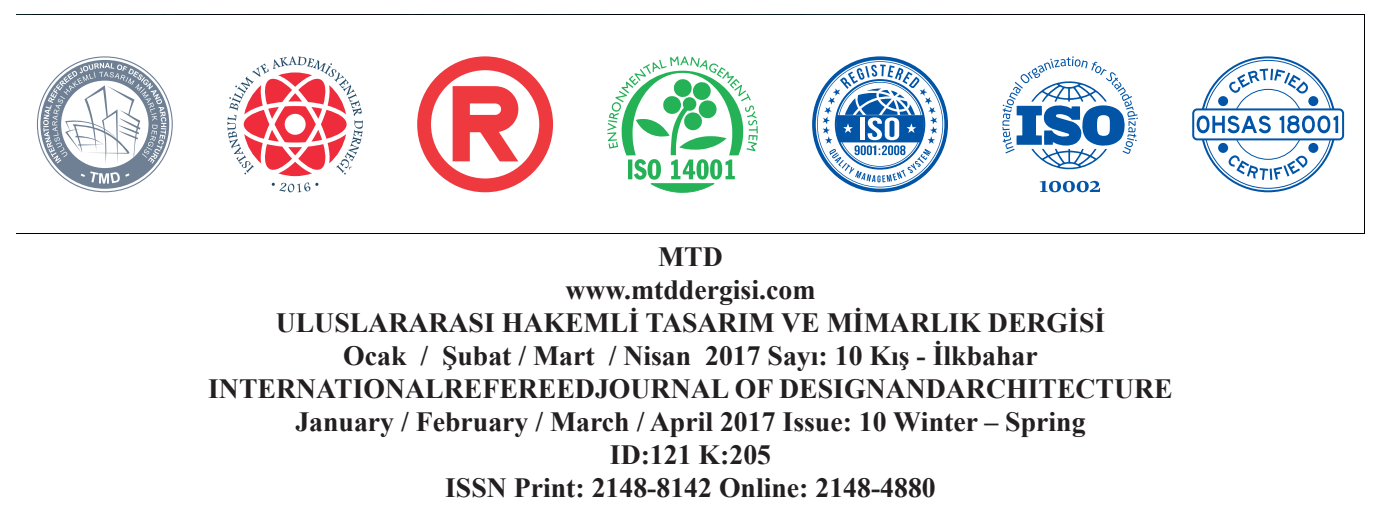

(ISO 18001-OH-0090-13001706 / ISO 14001-EM-0090-13001706 / ISO 9001-QM-0090-13001706 / ISO 10002-CM-0090-13001706)

(Marka Patent No / Trademark)

$(2015 / 04018-2015 / G E / 17595)$

programs related to climate, net area and volume assumptions and construction type, as well as the defaults of each program, such as correlation coefficients and average values.

Table 1. Convergence of the Results of EnAd for Heating, Cooling, DHW and Lighting

\begin{tabular}{|l|c|c|c|}
\hline & DesignBuilder & HAP & EnerCalc \\
\hline Heating & $-18 \%$ & $3 \%$ & $5 \%$ \\
\hline Cooling & $-22 \%$ & $8 \%$ & $1 \%$ \\
\hline DHW & $9 \%$ & $-4 \%$ & $-28 \%$ \\
\hline Lighting & $17 \%$ & $10 \%$ & $-8 \%$ \\
\hline
\end{tabular}

\section{Usability of EnAd}

Usability tests are also conducted to test the flexibility and ease of use of EnAd. The usability of the program is tested by means of a prepared protocol, designed to check the circumstances under which users have trouble with questions, options, values, explanations and activities. The results of the usability test reveal that the program is proven in its usability, understandability, efficiency and sufficiency, while also being informati- ve for the user. They validate the usefulness of the explanations and feedback provided by the program in improving the design. The results also show that using EnAd to assess the energy performance of a building is not a time consuming process, and can be done without the need for complex models. As a part of the usability test, Figure 14 presents time spent for each step of data input (steps 1-4) and improvement of the design (steps 5-10) in EnAd. 


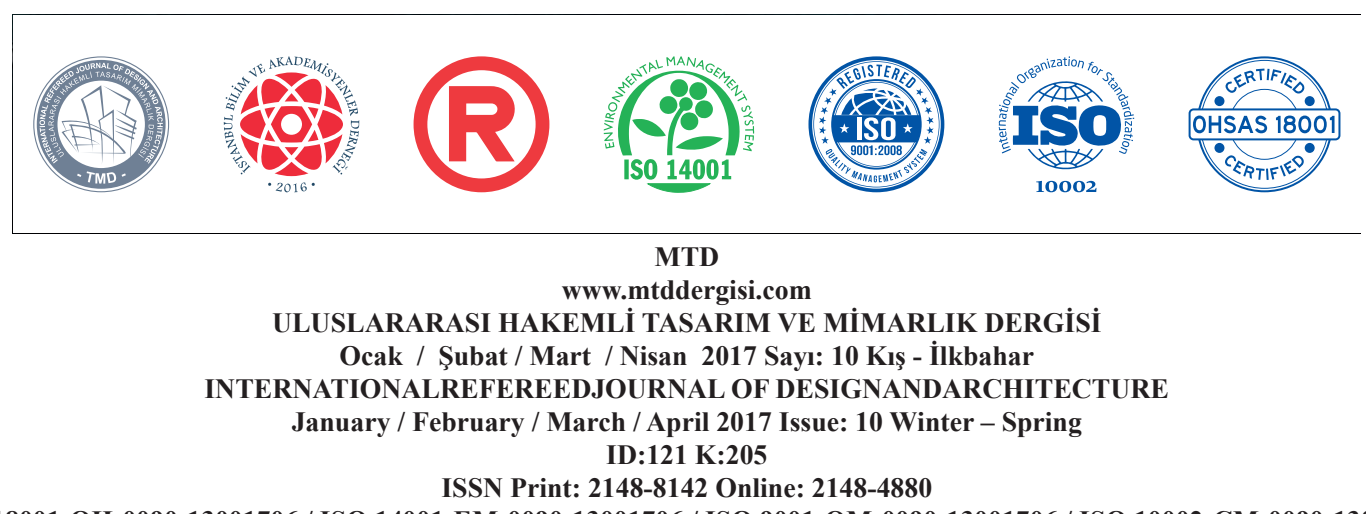

ISSN Print: 2148-8142 Online: 2148-4880

(ISO 18001-OH-0090-13001706 / ISO 14001-EM-0090-13001706 / ISO 9001-QM-0090-13001706 / ISO 10002-CM-0090-13001706)

(Marka Patent No / Trademark)

$(2015 / 04018-2015 / G E / 17595)$

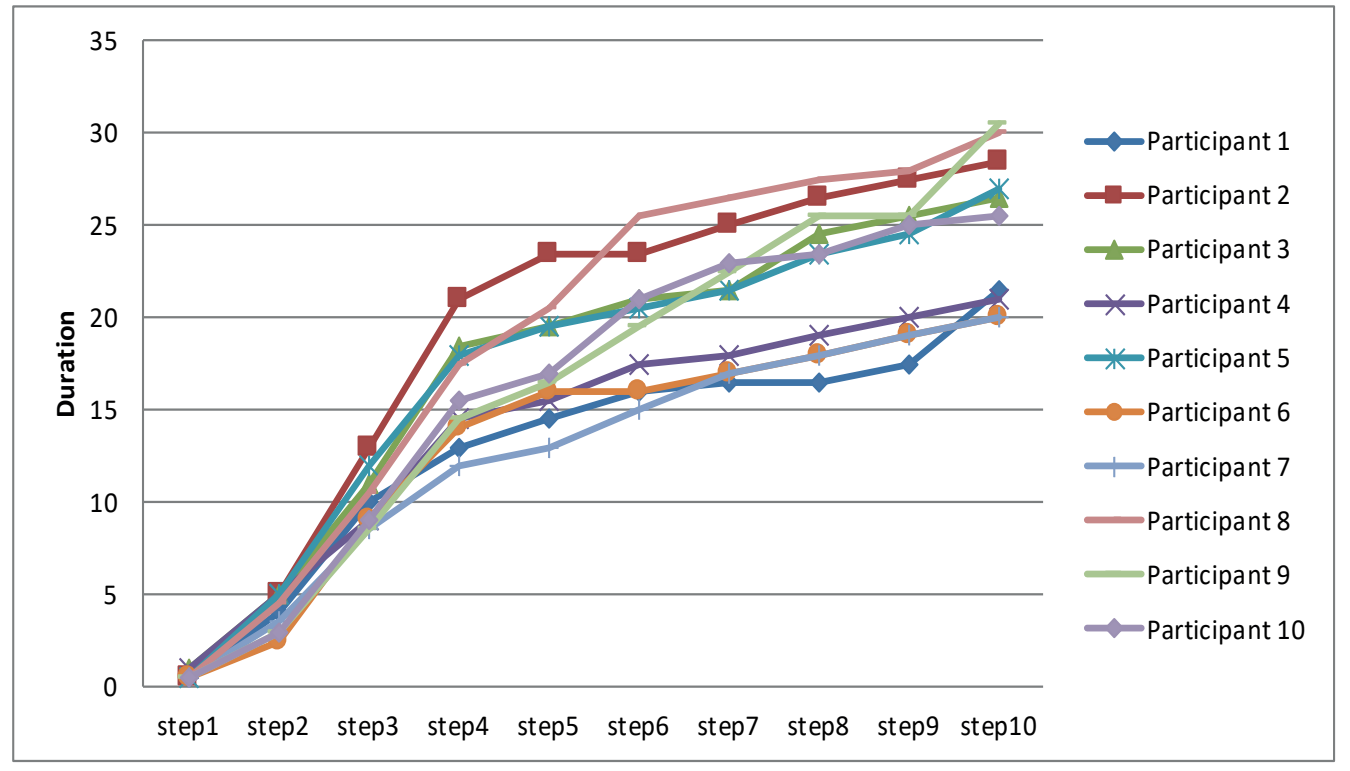

Figure 14. Time Spent for Each Step of the Design in EnAd

CASE STUDY: EVALUATION of a LOWRISE BUILDING

\section{Description of the Case Study}

In this section, the use and major features of EnAd has been exemplified on a single-family house, which is located in the western part of Ankara. The house selected for the case study is a terrace house, inhabited since 1994. The terraces on the site feature between three and five houses; and the house selected for the study is the center dwelling in a terrace of three houses, oriented in an east-west direction. The total floor area of the house is $115 \mathrm{~m}^{2}$, of which $60 \mathrm{~m}^{2}$ is the ground floor while the upper floor is $55 \mathrm{~m}^{2}$. The ground floor contains a living room, kitchen and toilet, and upstairs there are three bedrooms and a bathroom. The house features one meter wide cantilever floors on the first floor, and there are no balconies. The house is constructed using a sandwich wall system and has an unconditioned pitched roof. The ground floor is in contact with the earth, having no basement. It has low insulated walls with a U-value of $0.80 \mathrm{~W} / \mathrm{m}^{2} \mathrm{~K}$, and a moderately insulated ground floor (0.60), ceiling (0.35) and cantilever floors $(0.40)$. The windows are the standard type for Turkey having a U-value of 2.20 while a very low window-wall ratio (WWR) is used, which is about $8 \%$. Architectural drawings of the building are provided in Figure 15. 


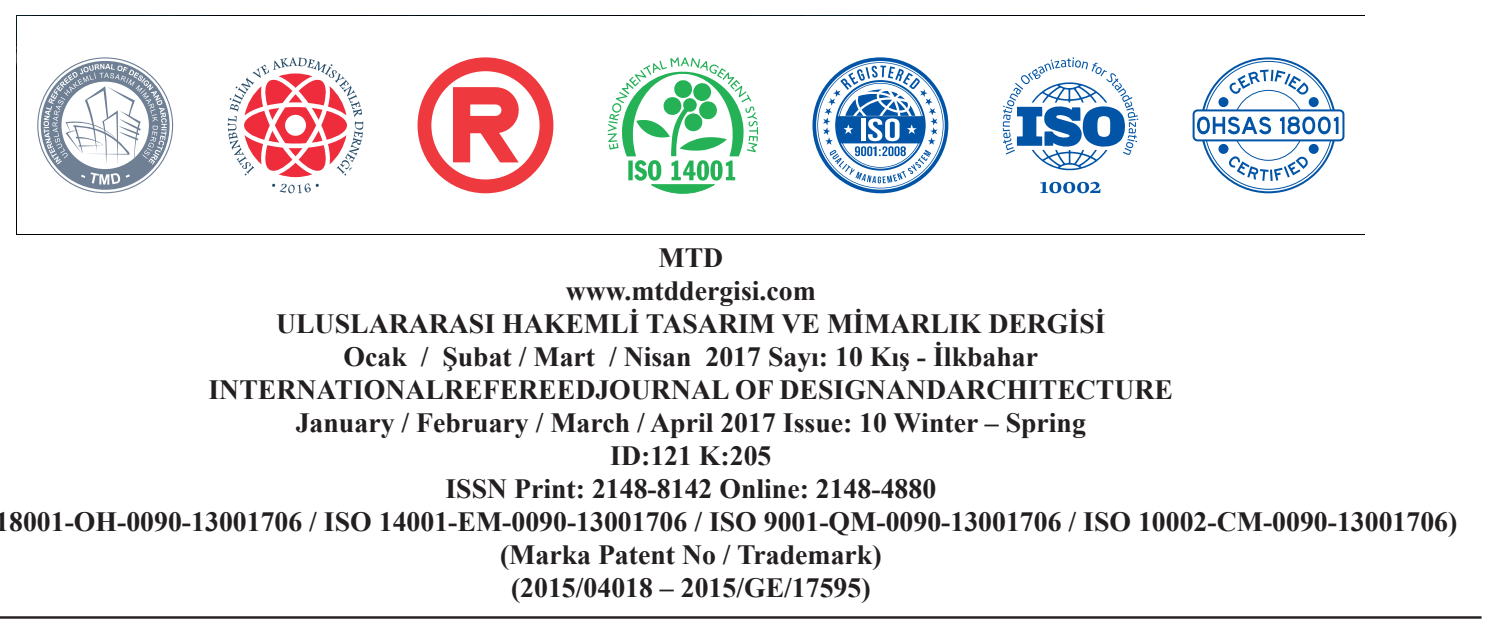

Table 2. Evaluation Results for the Terrace House in Ankara
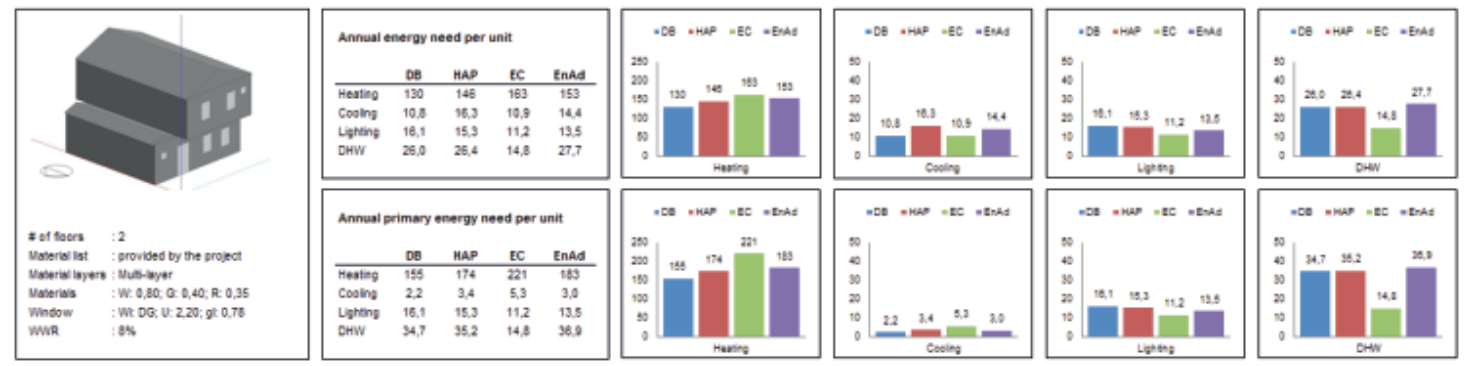

The evaluation results of the annual energy need and energy use of the building are presented in Table 2. Among other three programs, EnAd shows average results for energy need for space heating, cooling, DHW and lighting. The closest results to EnAd is observed in HAP, and followed by EnerCalc. DesignBuilder, on the other hand, shows the most diverse results for all conditions. The result of EnAd for energy need for heating differs from HAP by 5\%, EnerCalc by $7 \%$, and DesignBuilder by $15 \%$. For cooling, it is lower than HAP as $13 \%$ while being higher than EnerCalc as 24\% and DesignBuilder as
25\%. The result of EnAd for energy need for lighting differs from HAP by $-13 \%$, EnerCalc by $17 \%$ and DesignBuilder as $-19 \%$, while that for DHW supply is higher than HAP as $5 \%$, EnerCAlc as $47 \%$ and DesignBuilder as $6 \%$. Regarding the energy use of the building, the difference between the results is getting higher as a result of the conversion coefficients used by the programs. The convergence of the results of EnAd to the other three programs for energy use for heating is about $-21 \%-15 \%$; for cooling about $-77 \%-27 \%$; for lighting about $-19 \%-17 \%$; and for DHW supply about $5 \%-60 \%$. 


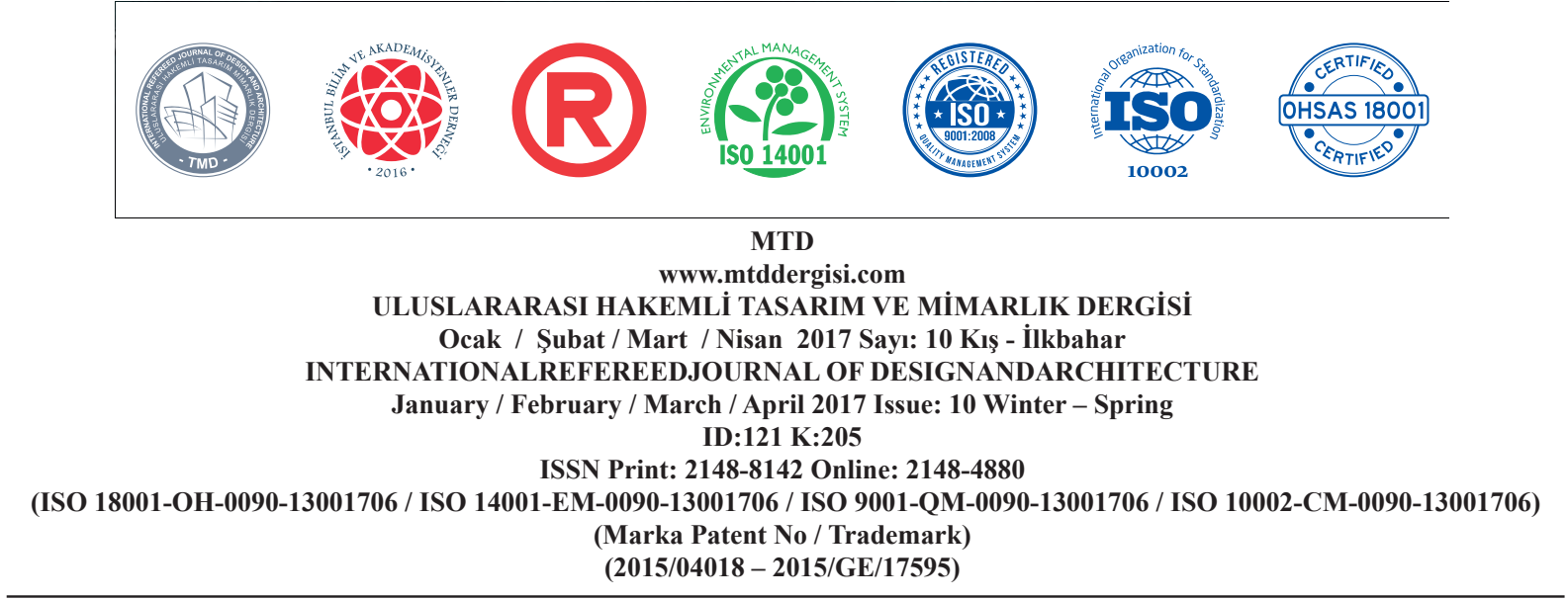

As shown in Figure 16 and Figure 17, the annual energy consumption for space heating of the building is found by EnAd to be 20,191 $\mathrm{kWh}$, and 4,075 kWh for DHW for the entire building. Based on these results, annual natural gas consumption is calculated at $1,898 \mathrm{~m}^{3}$ for space heating and $383 \mathrm{~m}^{3}$ for DHW, meaning about $2,281 \mathrm{~m}^{3}$ in total. These results are very close to the data taken from the utility bills, which showed about $2,429 \mathrm{~m}^{3}$ of natural gas consumption annually. Regarding electricity consumption, EnAd only gives results on energy requirements for lighting, disregarding the requirements for other electrical equipment in a building. According to the results provided by EnAd, the building requires $1,491 \mathrm{kWh}$ of electricity for artificial lighting, and so the remaining annual electricity consumption of $3,275 \mathrm{kWh}$ may be attributed to other home appliances. Differences in results may be attributed to the thermal bridges, window shading, shading from outside objects, occupant behaviors as well as the schedules of the building systems and occupancy.

\section{CONCLUSIONS}

In this paper, it is aimed to discuss the importance of integration of energy evaluation tools to the whole architectural design process as well as the possible role of legislative framework in improving the energy performance of buildings through the soft tool introduced in this study. EnAd as the soft tool developed to respond to such discussions has been described and illustrated on a case study. The most important contribution of the tool development process and the tool itself to the literature is that EnAd enables the determination of missing documents in the legislation, inconsistencies between the documents (including overlaps or contradictions), and missing values and performance criteria in the documents and in the national database that are necessary for the evaluation of the energy performance of buildings. Another contribution relates to the information provided during the use of the program. EnAd, provides warnings and feedback based on current legislation, the reference building and the improved case for the improvement of the design, while allowing the designer to follow the effect of each design decision on the results and on the energy performance class of the building. The conducted usability tests reveal the informative nature of EnAd, and prove its usefulness with the explanations and feedback provided for improving the design. In this respect, the program brings a unique and highly informative function to the field.

Schlueter and Thesseling (2009:153-154) assert that it is very important for a designsupport tool to give tendencies for design decisions instead of giving very precise results in early design phases, which has also been 


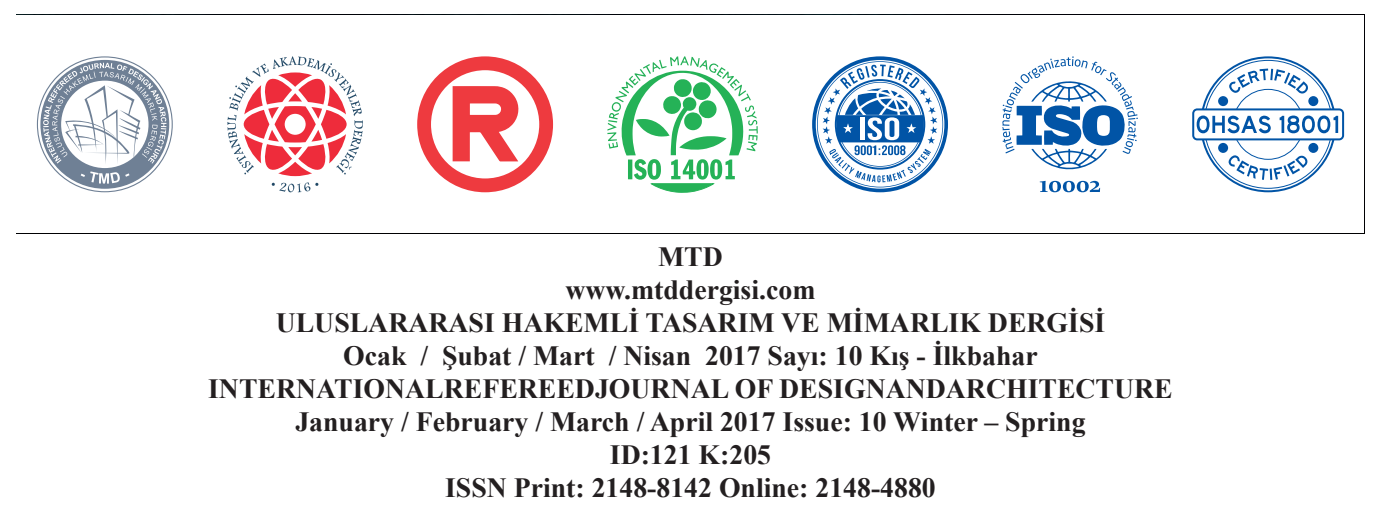

(ISO 18001-OH-0090-13001706 / ISO 14001-EM-0090-13001706 / ISO 9001-QM-0090-13001706 / ISO 10002-CM-0090-13001706)

(Marka Patent No / Trademark)

$(2015 / 04018-2015 / G E / 17595)$

accomplished by EnAd. Usability tests show that energy performance evaluation of buildings can be performed easily and quickly, and the tool can be used recursively for the improvements of the design while informing about the design limits and the related legislation on the subject. Other advantages the program offers include easy to use, usable in all phases of the building design process while providing numerical and graphical outputs for the energy performance.

As a conclusion, decision makers, from students to designers, and from architects to engineers, should be fully aware of the effects of their decisions on the energy performance of buildings. While legislation is the means by which international and national policies are put into practice, all legislation should be organized as a "guideline" to the architectural design process to assist the decision makers in their assigned tasks. Legislation aims to satisfy minimum targets; however they should also provide optimum values/criteria for the optimization of design. As shown in the case study, the existing building studied only satisfies the maximum limits of the legislation. Rather than being satisfied with achieving the minimum requirements, decision makers should be encouraged to aim for the best possible solution.

\section{REFERENCES}

BUILDING ENERGY SOFTWARE TOOLS DIRECTORY, (2016). http://apps1.eere. energy.gov/buildings/tools_ directory/, Accessed on: 02.02.2016

ÇAKICI, F.Z., (2013). The Development of a Building Energy Performance Evaluation Program (EnAd) for Architectural Design Process, $\mathrm{PhD}$ dissertation, Middle East Technical University, Department of Architecture, Ankara

COM, COMMISSION OF THE EUROPEAN COMMUNITIES. (2006).

Final Report on Action Plan for Energy Efficiency: Realizing the Potential, report number 545, Brussels, 19.10.2006

DIRECTIVE 2002/91/EC of the European Parliament and of the Council of 16 December 2002 on the Energy Performance of Buildings, Official Journal of the European Communities, 04.01.2003, L 1/65-71

DIRECTIVE 2010/30/EU of the European Parliament and of the Council of 19 May 2010 on the Indication by Labelling and Standard Product Information of the Consumption of Energy and Other Resources by Energy-Related Products, Official Journal of the European Communities, 18.6.2010, L 153/1-12 


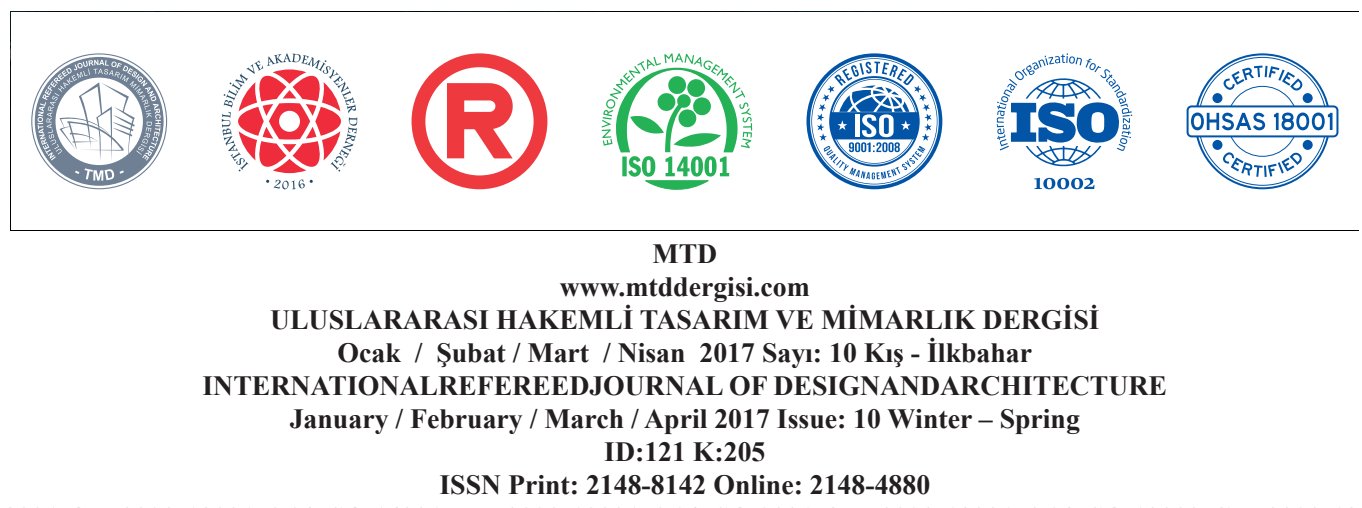

ISSN Print: 2148-8142 Online: 2148-4880
(ISO 18001-OH-0090-13001706 / ISO 14001-EM-0090-13001706 / ISO 9001-QM-0090-13001706 / ISO 10002-CM-0090-13001706)

(Marka Patent No / Trademark)

$(2015 / 04018-2015 / G E / 17595)$

EIA, ENERGY INFORMATION ADMINISTRATION. (2012). Annual

Energy Outlook 2012, Washington, DC, February 2012

KIBERT, C.J., (2002). Policy Instruments for a Sustainable Built Environment, Journal of Land Use \& Environmental Law 17(2): 379-394

KOLAREVIC, B., (2005). Performative Architecture Beyond Instrumentality, Branko Kolarevic and Ali M. Malkawi, eds., Spon Press, London, p.3

LEE, W., YIK, F.W.H., (2002). Regulatory and voluntary approaches for enhancing energy efficiencies of buildings in Hong Kong, Applied Energy 71: 251-274

\section{REGULATION ON ENERGY PERFORMANCE IN BUILDINGS} (Binalarda Enerji Performans1 Yönetmeliği), the Ministry of Environment and Urbanization (Çevre ve Şehircilik Bakanlığı) Resmi Gazete (Official Gazette), date: 05.12.2008, issue number: 27075, Ankara

SCHLUETER, A., THESSELING, F., (2009).

"Building Information Model Based Energy/Exergy Performance Assessment in Early Design Stages", Automation in Construction 18: 153-163

YILMAZ, A.O., (2009). Renewable Energy and Coal Use in Turkey, Renewable Energy 33: 950-959

\section{NOTES}

1. TS EN ISO 13790 Thermal Performance of Buildings.

2. The US Department of Energy (DOE) develops, promotes and invests in new tools and software programs related to energy efficiency and renewable energy technologies.

3. TS EN 15217 Energy Performance of Buildings - Methods for Expressing Energy Performance for the Energy Certification of Buildings.

4. TS 825 Thermal Insulation Requirements for Buildings.

5. $\mathrm{prCEN} / \mathrm{TR} 15615$ Explanation of the General Relationship between various European Standards and the Energy Performance of Buildings Directive (EPBD) - Umbrella Document.

6. TS EN 15603 Overall Energy Use and Definition of Energy Ratings. 